\title{
Çevre Koruma Bilinci Bağlamında İç Mekânın Tasarımında Disiplinler Arası Bir Yaklaşım: İç Mimarık ve Çevre Mühendisliği iliş̧isi
}

\author{
Deniz Demirarslan ${ }^{1, *}$, Kazım Onur Demirarslan² \\ ${ }^{1}$ Kocaeli Üniversitesi, Mimarlık ve Tasarım Fakültesi, İç Mimarlık Bölümü, 41100, Kocaeli. \\ ${ }^{2}$ Artvin Çoruh Üniversitesi, Mühendislik Fakültesi, Çevre Mühendisliği Bölümü, 08100 Seyitler, Artvin.
}

\section{Özet}

Dünyada özellikle 20. yüzyılın son yarısından itibaren bilim ve teknoloji alanlarında yaşanan gelişmeler yeni araştırma ve yaklaşımları ortaya çıkarmaktadır. Bu araştırma ve yaklaşımların sonuçlarının ortaya konmasında günümüzde tek bir alanda düşünme ve değerlendirme yapmak yeterli değildir. Tek bir disiplin ile yeni gelişen alanları incelemek mümkün olmamaktadır. Bu düşünce ve değerlendirmeleri destekleyecek diğer disiplinlerden faydalanılması söz konusudur. Bu bağlamda, disiplinler arası yaklaşıma ihtiyaç duyulmaktadır. Günümüzde teknoloji ve bilimin ilerlemesi, inşaat teknolojisindeki gelişmeler ve yaşam gereksinimlerinde görülen değişimler sonucu daha yaşanılabilir, gelecek nesillere aktarılabilir, yapımları ve kullanımları sırasında çevreye daha az zarar veren mekânların tasarımı artık bir tasarım eğilimi olarak kabul görmektedir. Dolayısıyla çevreye duyarlı mekânlar oluşturmada iç mimarlı tek başına yeterli olmamaktadır. Bu süreçte çevre mühendisliği ile ilgili konularda destek almaya ihtiyaç duyulmaktadır. Bu çalışmada, bir tasarım disiplini olan iç mimarlık ile bir mühendislik disiplini olan çevre mühendisliğinin disiplinler arası bir yaklaşım ile ele alınarak, ortak paydalarının bulunması ve çevre mühendisliğinin iç mimarlığa katkılarının belirlenmesi amaçlanmaktadır. Çalışma kapsamında öncelikle disiplinler araš çalışma özellikleri belirtilmiş, konuyla ilgili disiplinler incelenmiş ve iki disiplin arasındaki ortak paydalar örnekler ile açıklanmıştır.

\section{An Interdisciplinary Approach to Interior Design in the Context of Environmental Protection Awareness: Relation between Interior Architecture and Environmental Engineering}

\begin{abstract}
Developments in the fields of science and technology, especially since the last half of the 20th century, reveal new research and approaches in the world. In presenting the results of these researches and approaches, it is not enough to think and evaluate in a single field today. It is not possible to examine newly developed areas through a single disciplinary approach. It is the use of other disciplines to support these thoughts and evaluations. In this context, interdisciplinary approach is needed. Today, as a result of the advancement in technology and science, the development of construction technology and changes in the living necessities; designing architectural spaces that are more liveable, transferable to future generations, and causing less damage to the environment during their construction and use is now regarded as a design trend. Hence, interior architecture alone is not enough to create environmentally sensitive space. In this process, it is necessary to receive support for environmental engineering issues. In this study, it is aimed to handle both the interior architecture, a discipline of design, and the environmental engineering, a discipline of engineering with an interdisciplinary approach to find common grounds and to determine the contribution of environmental engineering to interior architecture. In the scope of the study, firstly, the interdisciplinary study features were mentioned, the related disciplines were examined and the common grounds between the two disciplines were explained with examples.
\end{abstract}

\section{$\underline{\text { Keywords }}$}

Environment, Ecological Design, Green Interior Design, Sustainability, Interior Architecture, Environmental Engineering,

\section{Giriş}

İnsanı çevreden belirli bir ölçüde ayıran ve içinde eylemlerini sürdürebilmesine elverişli olan boşluk olarak tanımlanan (Hasol 2012) mekânı tasarlama eylemi “insan gereksinimlerini karşılamak üzere fiziksel çevrenin düzenlenmesi” olarak tanımlanır. Bu eylem insanın yaratılışından bu yana onunla birlikte gelişip farklılaşarak günümüze dek gelmiştir. İlkel insanın barındığı mağara ve ağaç kovuklarından, ağaç kulübelerden günümüzün yüksek binalarına dek uzanan mekân tasarımının serüveni, tarih öncesi dönemlerden günümüze dek geniş bir gelişim sürecini kapsamaktadır. Bu süreç her türlü toplumsal, ekonomik ve teknolojik değişimden etkilenmektedir (URL-1 2017). 
$\mathrm{Bu}$ doğal ve sürekli etkileşim tarihin hemen her döneminde kendini göstermiştir. Toplumsal, ekonomik ve teknolojik alandaki değişimler mekânın tasarımında çeşitli yenilikler meydana getirmektedir.

Gelişen ve her geçen gün değişen dünyada sadece mekânın tasarımında değil; yaşamın her alanında yenilikler ortaya çıktığını görmekteyiz. Bu yeniliklerin ortaya çıkışında hiç kuşkusuz teknolojinin payı büyüktür. Teknoloji, bilimsel çalışmalardan yola çıkarak yeni bir ürün geliştirmek ve hizmet desteği sağlamak için gerekli bilgi, beceri ve yöntemler bütünü olarak tanımlanabilir. 21. yüzyılda, endüstrileşmesini tamamlayan ve teknolojik devrimle yeni bir dönem başlatan çağdaş toplumlar, içinde bulundukları dönemi, elektronik çağı, sibernetik çağ, üstün teknolojik çağ ya da bilgi çağı olarak adlandırmaktadır (Özturan 2007). Toplum ve bireyin yaşamında köklü değişimler yaratan Endüstri Devrimi gibi "Bilgi Çağı" da toplum ve bireyin yaşamını doğrudan etkilemektedir. Teknolojideki gelişmeler ve dönüşümler, çağdaş yaşamı değişim kavramının üzerinde ve onu etkileyen faktörlerin eşliğinde yeniden biçimlendirmektedir.

Çağdaş mekân olgusu ise iletişim, ulaşım, dolaşıma yönelik ve bunların etkilediği zaman, mekân, yaşam şekillenişi ve etkileşimi ile yeniden tanımlanmaktadır. Giderek daha da bireyselleşen kişilerin değişim gösteren gereksinimleri ve tüketim alışkanlıkları, kentlerin işleyişini değiştirmekte buna bağlı olarak mekân biçimlenişini de etkilemektedir (Özturan 2007). İnsan yaşamını belirleyen teknolojik gelişmeler, içinde yaşadığımız çevreyi de etkileyerek çevre koşullarını çoğunlukla olumsuz yönde etkilemekte ve mekânların biçimlenişine de egemen olmaktadır. Buna bağlı olarak mekân biçimlenişlerinin yeniden değerlendirilmesi gerekmektedir. Teknolojik gelişmeler mekânların oluşumunu, boyutsal, işlevsel, biçimsel olarak yenilenmesi ve çevre koruma bilinci açısından ele alınması gerekliliğini ortaya koymaktadır (Çelebi vd. 2008).

Disipliner yaklaşımın dar sınırları içinde bu yeni gelişen alanları incelemek artık yetersiz kalmaktadır. Bu bağlamda disiplinler arası yaklaşıma ihtiyaç artmaktadır. Disiplinler arası yaklaşımla çalışılan konular bilim ve teknolojinin çalışılan konu üzerinde daha etkili ve doğru bir şekilde kullanımını sağlamaktadır. Bu çalışmanın ana konusunu oluşturan bir tasarım disiplini olan iç mimarlık ile bir mühendislik disiplini olan çevre mühendisliği arasındaki ortak çalışma paydalarının bulunması, günümüzde önem kazanmaya başlayan çevre koruma bilinci bağlamında yeni gündeme gelen bir husustur.

Bir mekân oluşturma disiplini olan iç mimarlığın inşaat mühendisliği, makine mühendisliği, elektrik mühendisliği, elektronik mühendisliği gibi diğer mühendislik alanları ile olan ilişkisi günümüze değin bilinmekle beraber, çevre mühendisliği ile olan ilişkisi sürdürülebilirlik ve çevre koruma bilincinin mekân tasarımında dikkate alınmasıyla birlikte gündeme gelmiş olup; yeni bir disiplinler arası araştırma konusunu oluşturmaktadır.

Bu çalışmanın amacı, mekânın tasarımında geçmişteki altyapı sorunları ve bilinç eksikliği sonucu oluşan çevre sorunlarının çözümlenmesine yönelik bir tasarım benliğinin oluşturulmasında iç mimarlık ve çevre mühendisliği disiplinleri arasında bir bağıntının kurulmasında etkili olan hususların ortaya konmasıdır. Konu ile ilgili literatür taraması yapılarak, konuya yönelik tanımlar ve açıklamalar derlenmiş ve elde edilen veriler 1şığında tablo ve grafiklerin yardımıyla konunun yorumlanması sağlanmıştır. İç mimarlık ile çevre mühendisliği arasındaki ilişkinin araştırıldığı yayınların az oluşu çalışmanın önemini artırmaktadır.

Çevre sorunlarının günümüzde hızla artması, iç mimarları bu konuda araştırma yapmaya ve çözüm arayışına yönlendirmektedir. İç mimari uygulamaların çevreye olan zararlarını durdurmak için yeşil, ekolojik ve sürdürülebilirlik terimleri altında çevresel yaklaşımlar geliştirilmektedir. Çevresel yaklaşımlar aracılığıyla çevre sorunlarını önleyecek uygulamalar, araştırmalar ve çözümler önerilmektedir. Hangi terimle ifade edilirse edilsin temel amaç çevre tahribatını önlemektir. Çevresel yaklaşımlar aracılığıyla tüm disiplinler doğaya olan etkileri bağlamında sorgulanmakta ve bu alanlara dair yeni tanımlar yapılmaktadır. Diğer tasarım temelli disiplinlerle birlikte iç mimarlık alanına da bu süreçler yansımakta; ekolojik, biyoiklimsel, sürdürülebilir tasarımlar ve yapılar desteklenmektedir (Adıgüzel 2015).Çevre sorunlarının mekân tasarımlarında tasarımı yönlendirici bir etki olarak ele alınması olarak tanımlayabileceğimiz "tasarımda çevre koruma bilinci" diğer tasarım temelli disiplinlerde olduğu gibi iç mimari uygulamalarda ve konu ile ilgili akademik çalışmalarda sürdürülebilirlik kapsamında ele alınırken; bu çalışma çevre koruma bilinci kapsamında interdisipliner açıdan iç mimarinin çevre mühendisliği ile olan ilişkisini ve ortak paydalarını bulmak üzere konuya farklı bir bakış açısı getirmesi açısından önem taşımakta ve diğer çalışmalardan farklılaşmaktadır.

Çalışmanın birinci bölümünde konunun amacı ve yöntemi belirtilmiş, ikinci bölümde disiplinler arası yaklaşım konusunda önemli tanımlara yer verilmiş; üçüncü bölümde iç mimarlık, dördüncü bölümde çevre mühendisliği, disiplinleri hakkında genel bilgilendirme yapılmış, beşinci bölümde ise iç mimarlık ve çevre mühendisliği ilişkisi araştırılmış, altıncı bölümde çevre koruma bilinci bağlamında iç mimari tasarım incelenmiştir. Sonuçta her iki disiplinin disiplinler arası yaklaşımla ele alınarak, ortak paydaları belirlenmiş; bu ortak paydaların çevre koruma bilinci bağlamında gelecekteki mekânların tasarımına ve çevreye etkileri tartışılmıştır.

\section{Disiplin ve Disiplinler Arası Yaklaşım Kavramları}

Disiplin, kendine özgü eğitim alt yapısı, yöntemleri ve içeriği olan ve herhangi bir alanda yeni bilgi üretilebileceğini ve söz konusu alanda daha ileri düzeyde bilgiler geliştirilebileceğini kanıtlamış bir araştırma alanı olarak tanımlanmaktadır (URL-2 2017). Her disiplinin kendine özgü doktrini, profesyonel dili ve terminolojisi bulunur. Disiplinler arası "iki ya da daha fazla akademik disiplinin ya da inceleme alanının birleştirilmesi/kapsanmasıdır" (Chandramohan ve Fallows 2009). Disiplinler arası yaklaşım bir konuyu, alt başlı̆̆ 
disiplinin dilini ve yöntemlerini kullanan bilgi görüşü ve program yaklaşımıdır (Jacobs 1989). Erickson (1995)'a göre, disiplinler arası yaklaşım "farklı disiplinlerdeki kavramların kavramsal bütünleşmesi” olarak tanımlanmaktadır.

Disiplinler arası yaklaşım esasen yeni bir kavram olmayıp, 20. yüzyılda daha çok görülmeye başlamakla beraber, ilk kez Platon'un Politea'sında “disiplinler arası yaklaşım ile bütünleşme fikri” görülmektedir (URL-2 2017). Disiplinler arası terimi zamanla;

1. Çok disiplinli yaklaşım (Multidisciplinary)

2. Çapraz disiplinli yaklaşım (Crossdisciplinary)

3. Disiplinler ötesi yaklaşım (Transdisciplinary) olarak gelişim göstermişstir (Aktan 2007).

Çok disiplinli yaklaşım birden fazla disiplinin bütünleştirme yapılmaksızın tek bir konu üzerinde odaklanması olarak tanımlanır (Piaget 1972). Çapraz disiplinli yaklaşım bir disipline bir başka disiplinin perspektifinden bakılmasıdır. Örneğin; tasarım tarihi, mühendislik matematiği gibi çapraz disiplinli yaklaşım disiplinler arasında hem genişliğine hem de derinlemesine etkileşimi kapsar. Bu yaklaşım ile disiplinlerden birinin diğerine üstünlüğünü gerektirir (URL-2 2017).

Disiplinler ötesi yaklaşım ise birkaç disiplini aşıp; herhangi bir disiplinin ötesine geçen konular ile ilgilenilmesidir. Disiplinler ötesi terimindeki “ötesi” sözcüğü bütün alanların aralarındaki sınırların kalkmasını ve alanların ötesine geçilmesini belirtir. Amaç evreni kavramak için gerekli bilgi bütünlüğünü sağlamaktır (URL-2 2017). Çevre koruma bilinci bağlamında iç mekânın tasarımında disiplinler arası bir yaklaşım olarak iç mimarlık ve çevre mühendisliği ilişkisinin irdelenebilmesi için öncelikle her bir disiplinin tanımlarının yapılarak bu disiplinleri meydana getiren temelleri ve çalışma alanlarına değinmek gerekmektedir.

\section{3. İç Mimarlık Disiplini}

İnsanın ve toplumun mekân ihtiyacı bir iç mimarlık yapıtının oluşmasını gerektiren nedendir. Mekân ihtiyacı eşya ve eylemler için hacim ihtiyacı, varlığımızı sürdürmek için güvenlik ihtiyacı, yaşamı sürdürmek için konfor ve estetik ihtiyacı olarak tanımlanır. İç mimarlık bu ihtiyaçları karşılayarak mekân oluşturan ve örgütleyen bir tasarım disiplinidir (Demirarslan 2006). Düşünülerek tasarlanmış mekânlar öğrenmemize, hayal etmemize, keşfetmemize ve yaratmamıza yardımcı olur. İç mimar, insan ve çevre ekolojilerini sentezler ve bilimi tüm duygulara hitap edecek biçimde güzelliğe çevirir. İç mimarlar kültürel sermayeyi yorumlayan, dönüştüren ve düzenleyen mekân yapıcılarıdır (URL-3 2017; Hayles 2015).

İç mimar, iç mekân yapı bileşenlerini ve donatı elemanlarını detaylı olarak tasarlayarak, mekânların ve yakın çevresinin kullanıcı ihtiyaçları ile ölçülerini dikkate alarak estetik açıdan uygun olmasını sağlar (Kazamia ve Kafaridou 2010). Mekânda aydınlatma, ses düzeni, yalıtım, iklimlendirme gibi fiziksel ortamın sağlanmasının yanı sıra malzeme araştırmaları da görevleri arasındadır (Şekil 1). Meslek olarak 19. yüzyılın ortalarında çıkmış olan iç mimarlık mesleği özellikle 20. yüzyılın ikinci yarısından itibaren artan çevreci yaklaşımların etkisinde kalarak yeni tasarım eğilimleri ortaya çıkarmıştır. Bu tasarım eğilimlerinden başlıcaları da ileriki bölümlerde tanımlanan çevre koruma bilinci ile ortaya çıkan sürdürülebilir mekân tasarımı, ekolojik mekân tasarımı ve yeşil iç mimaridir.

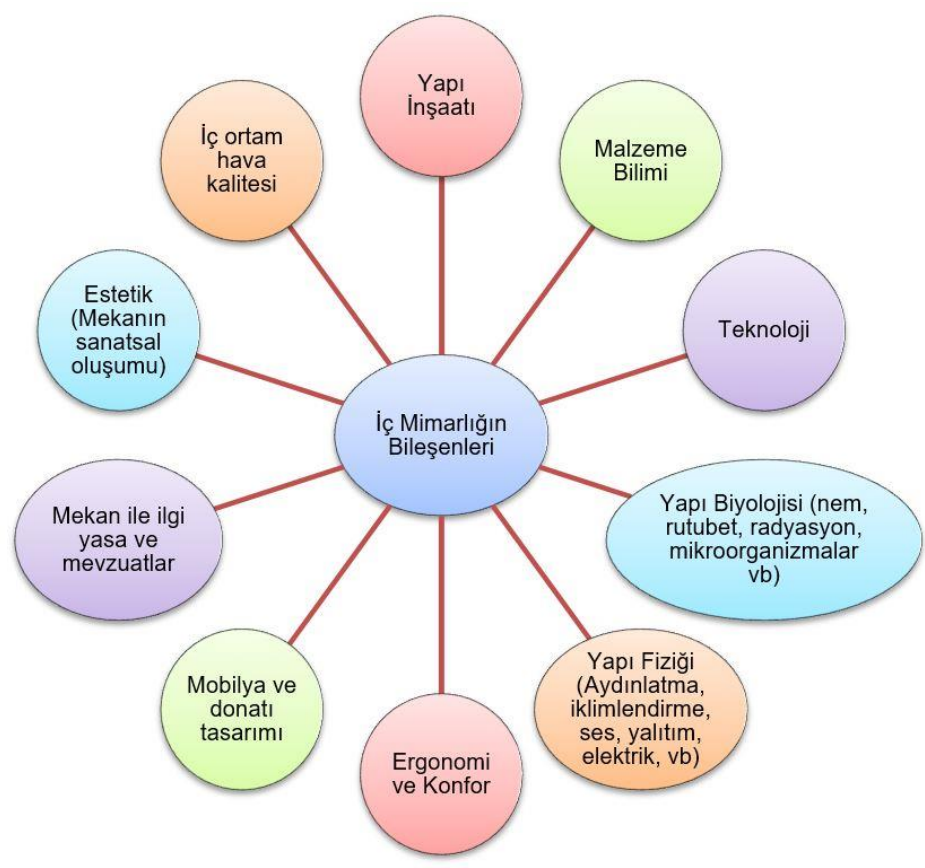

Şekil 1: Iç mimarlık disiplininin bileşenleri (Demirarslan 2016) 


\section{4. Çevre Mühendisliği Disiplini}

Çevre, insanların ve diğer canlıların yaşamları boyunca ilişkilerini sürdürdükleri ve karşılıklı olarak etkileşim içinde bulundukları fiziki, biyolojik, sosyal, ekonomik ve kültürel, içinde yaşadığımız ortamdır. Doğal dengeyi oluşturan zincirin halkalarında meydana gelen kopmalar zincirin tümünü etkileyip, dengenin bozulmasına neden olmaktadır. Dengenin bozulmasında en önemli faktör insandır. Çünkü insanın yaşamını sürdürmesine ve faydalanmaya yönelik yaptığı her davranış ve her yenilik doğal dengeyi etkilemektedir (URL-4 2017).

Çevre mühendisliği yerel ve küresel ölçekte, insanları çevrenin, çevreyi de insanların olumsuz etkilerinden korumak, insan sağlığı ve refahı için çevre koşullarını iyileştirmek yönünde temel bilimsel kavramları uygulamaya koyan mühendislik dalıdır (URL-5 2017; Cooper 2014). Bir diğer tanıma göre; çevre mühendisliği çevre kirliliğinin önlenmesi kapsamında çevre yönetim sistemleri ve planları, çevresel etki değerlendirmesi, su kirliliği ve arıtımı, katı atıklar, zehirli ve tehlikeli atıklar, evsel ve endüstriyel atıklar, hava kirliliği, gürültü, toprak ve yer altı suyu kaynaklarının kirliliği ile ilgilenen mühendislik dalıdır (22 Nisan 2009 tarih ve 27208 sayılı Resmi Gazetede yayınlanan TMMOB Çevre Mühendisleri Odası Çevre Mühendislik Hizmetleri Uygulama ve Asgari Ücret Yönetmeliği 5. ve 6. Madde) (URL-6 2017) (Şekil 2).

Hava ve su kaynaklarının temizliği, çevresel kalite, kirlilik ve kontrol süreçleri, katı atık ve tehlikeli atık yönetimi, kirlenmiş toprak alanlarının iyileştirilmesi, toprağın korunması amacıyla mühendislik ilke ve teknolojilerini kullanan bu disiplin çevresel sorunlara interdisipliner bir şekilde çözüm bulmaktadır (Cooper 2014; Maczulak 2009).

1960'lı ve 1970'li yıllardan itibaren artan çevre sorunlarına karşı tüm dünyada çevreci hareketler baş göstermiş ve yasal düzenlemeler ile kurumsal yapılanmaların yanında üniversitelerde çevre konusunda teknik eğitime yer verilmeye başlanmıştır (Cooper 2014; Samsunlu 2000).

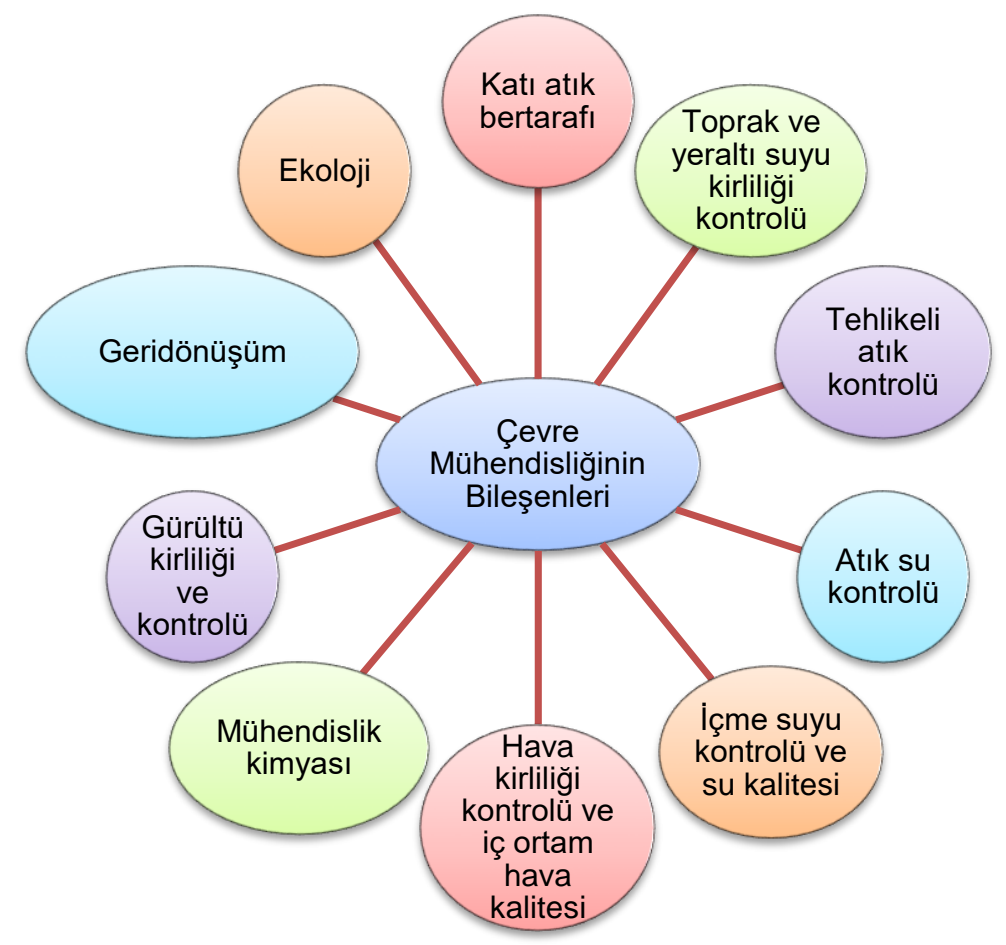

Şekil 2: Çevre mühendisliğinin bileşenleri (Fränzle vd. 2012)

\section{5. İç Mimarlık Mesleği ile Çevre Mühendisliği İlişkisi}

Mekân ve doğa arasındaki etkileşim oldukça ilişkili ve karmaşıktır. Çünkü insan eliyle oluşturulan mekânlar diğer insan yapımı oluşumlara göre daha uzun bir kullanım ömrüne sahiptir. Mekânların tasarım, yapım, kullanım, bakım ve yıkım/yeniden kullanım aşamaları süresince doğa ile etkileşimleri olmaktadır. Ayrıca, gelişmiş ve gelişmekte olan ülkelerde insanlar yaşamlarının \%80-\%90'nını bina içinde geçirmektedirler (Yurtseven 2007). Bu durum da mekânların insan sağllğı üzerinde etkisi anlamında önemlidir.

Yukarıda belirtildiği üzere, iç mimarlık insanın yaşamsal ihtiyaçlarını karşılayacağı mekânları ve yakın çevrelerini tasarlayan bir tasarım disiplinidir. İç mimarlık ile mimarlık arasındaki önemli fark ise genellikle iç mimarların mevcut yapı stoklarını kullanarak ve yakın çevrelerini yeniden ele alarak çoğunlukla farklı işlevler ve ihtiyaçlar için yeniden tasarlamalarıdır (Şekil 3). 
İşlevini yitirmiş mekânlara uygun bir işlev ve bir miktar müdahale ile yeniden işlevlendirme örnekleri oldukça yaygındır. Bu uygulama sayesinde günümüzde şehir merkezlerinde mevcut yapı stokları kullanıldığı için boş araziler doğal çevre olarak kalabilmekte ve binaların doğal çevreye zararı indirgenebilmektedir. Ancak mevcut yapı stokunun yeniden tasarlanarak kullanımı anlamına gelen iç mimarlık uygulamalarının yine de çevreye zararlı etkileri olmaktadır. Bu süreç büyük oranda tadilat, yıkım, bakım ve onarım işlerini gerektirmektedir. Bu sürece malzeme seçimi ve kullanımı, sıhhi tesisat, iklimlendirme, 1sıtma tesisatı, yalıtım, mobilya ve donatı gibi fiziksel mekânı oluşturan diğer teknik konular da eklenince iç mimarlık çok yönlü ve çok disiplinli araştırma ortamı gerektiren karmaşık bir disiplin haline dönüşmektedir. Bu çok yönlü ve çok disiplinli araştırma gerektiren çalışma yapı, mobilya, yapı malzemesi üretim sektörleri ile yakından ilişkili olup; işlerin uygulanması sırasında büyük ölçüde çevreye zarar verilmektedir (Şekil 4). Dolayısıyla iç mimarlık işlerinin çevreye zarar verici etkilerinden söz etmek mümkündür. İç mimarlık ve çevre arasındaki ilişkinin daha iyi anlaşılabilmesi için örnekler ile konunun desteklenmesi gerekmektedir.

Belirtildiği üzere iç mimarlık yapı, mobilya ve yapı malzemesi sektörleri ile yakından ilişkilidir. Yapı sektörünün bir parçası olan binalar yeşil alanların yok olması, temiz su kaynaklarının bozulması, ozon tabakasının yıpranması gibi küresel anlamda sürekli bir yıpranmaya neden olmaktadır. Dummet (2007)'a göre Finlandiyalı çevre ekonomisti Heiskanen bir tasarım ürünü olan mekânın çevreye olan etkisinin \%70'inin daha tasarım aşamasında oluştuğunu belirtmektedir. Mekânın tasarımında iç mimarlık disiplininin çevre mühendisliği ile ilişkinin kurulmasında;

○ Kaynak kullanımı

- Atıklar

- Gürültü

- Hava kalitesi etkili olan dört husustur (Elias 2003; Kazamia ve Kafariou 2010; Kibert 2000; Hayles 2015) (Şekil 5).

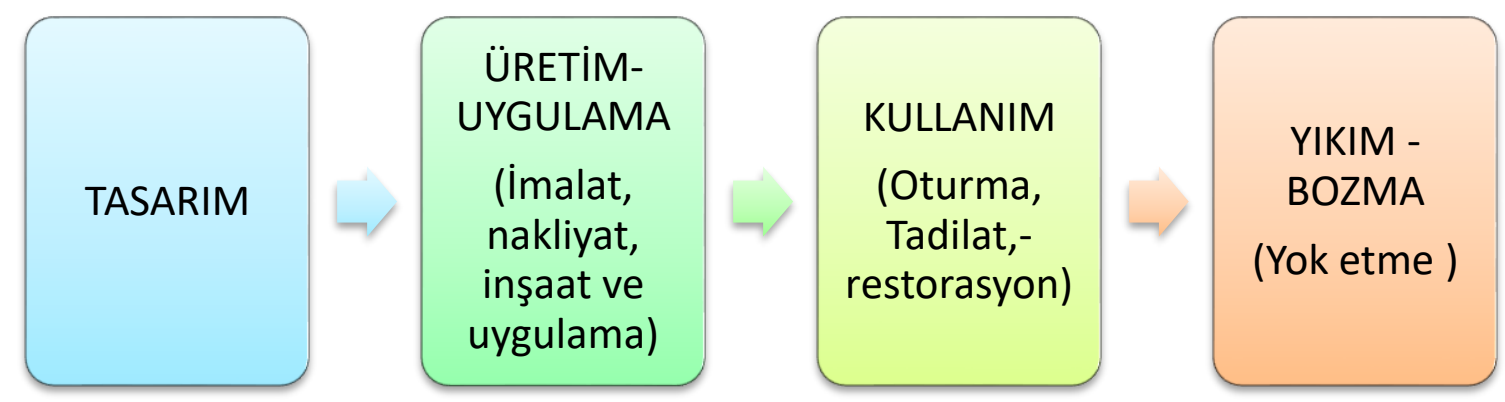

Şekil 3: Mekân ve mekân elemanı tasarımı ve kullanımının evreleri

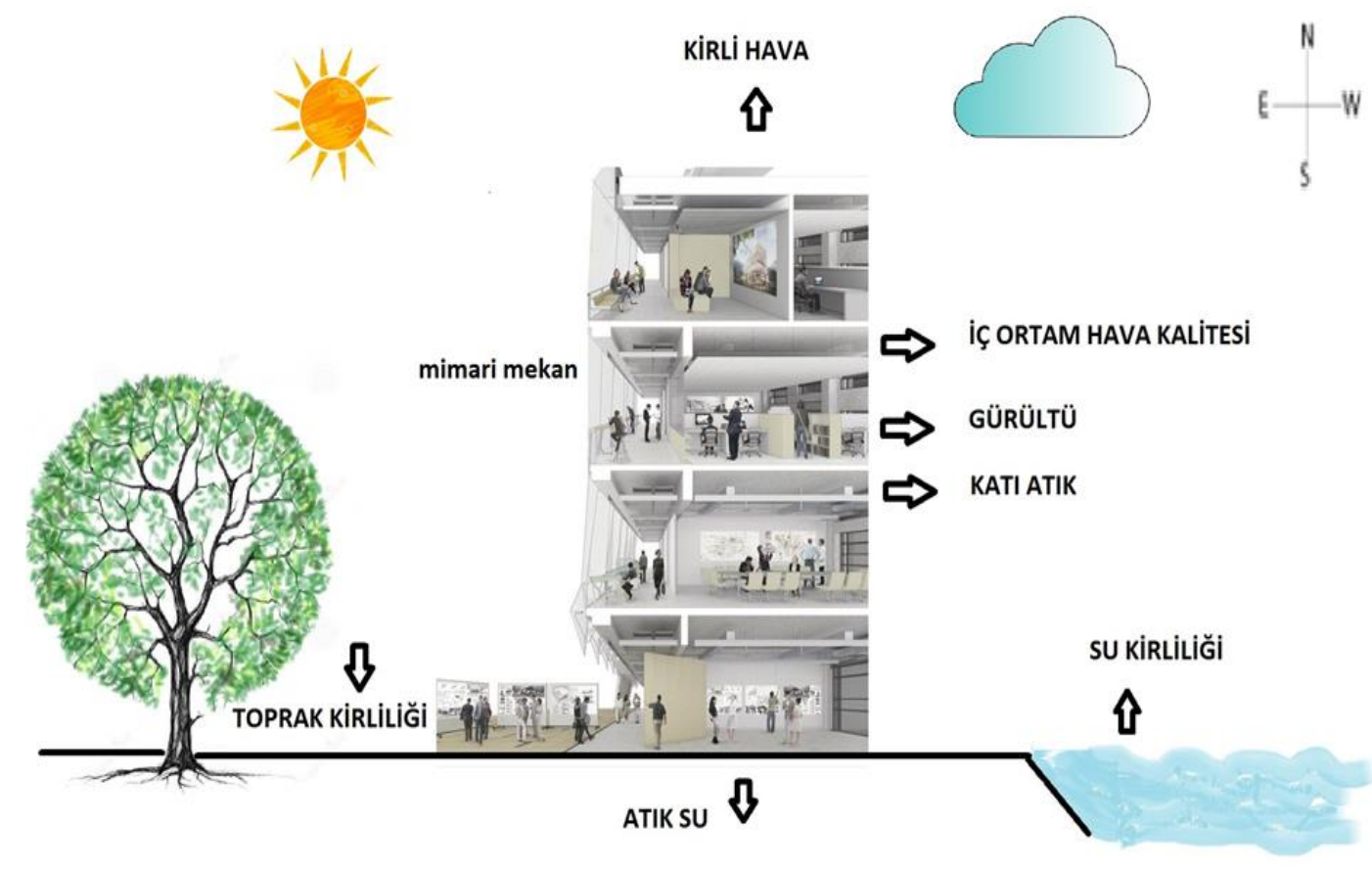

Şekil 4: Mekânın tasarımının çevreye etkileri 
Edwards (2001)'a göre; çevre kirliliğinin oluşumunda hava kalitesinin \%24'ü, içme suyu kirliliğinin \%40'1, katı atıkların \%20'si, küresel ısınmaya neden olan gazların \%50'si, Kloroflorokarbonların (CFC ve HCFC) \%50'sinden binalar sorumludur. Wines (2008)'a göre ise dünyanın tatlı su kaynaklarının 1/6'sının, kesilen ağaçların 1/4'nün ve fosil yakıtlar ve üretilen gereçlerin 2/5'nin tükenmesinden mekânların tasarım ve uygulanması sorumludur.

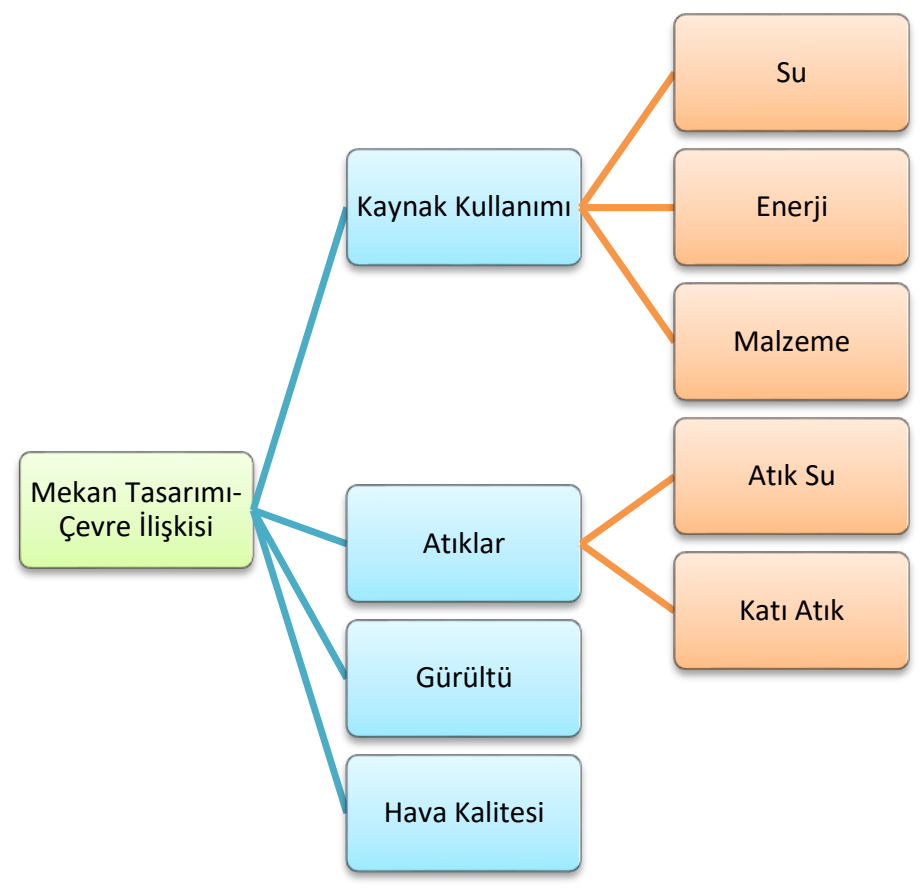

Şekil 5: Mekân tasarımı- çevre ilişkisi

\subsection{Kaynak Kullanımı}

Yapı ve mobilya sektöründe su, enerji ve malzeme olarak üç ana kaynak kullanılmaktadır (Özmehmet 2007) (Şekil 5). Yapılar uygulanma ve kullanım süreçleriyle dünya genelinde su tüketiminin \%42'sinden sorumludur. Ayrıca içme suyu kirliliğinin \%24'ü yapıyla ilişkili faaliyetlerden kaynaklanmaktadır (Eryıldız 2003). İç mekânda ise sıhhi tesisat mekânın kullanım aşamasında sıvı ve katı atıkların miktarlarını minimuma indirmek üzere düzenlenmiş tesisat sistemidir. Çevresel yaklaşımla mekân tasarımında su kullanımını azaltacak sıhhi tesisat tasarımı ve suyun etkin kullanımına yönelik araç ve donatıların seçilmesi şeklinde uygulamalar yapılmaktadır. Örneğin; mekânda 1slak hacim olarak isimlendirilen birimler birbirlerine yakın olarak planlandıkları takdirde su tüketimi \%30 oranında azaltılabilmektedir. Ya da su tüketimi kontrolü olan donatıların kullanımı ile su tüketimi \%20-25 oranında azalmaktadır (Adıgüzel 2011). İçme suyundaki kirlenmenin \%40’1 da mekânların oluşumundan kaynaklıdır. Sürdürülebilir mekân tasarımlarının ve akıllı bina teknolojilerinin önemli bir parçası olan kirli suyun arıtılarak yeniden kullanımı ise doğrudan çevre mühendisliği ve iç mimarlık ilişkisinin kurulmasını sağlayan bir çalışma olup; kirli suyun arıtılarak bahçe, iklimlendirme sistemleri, tuvalet ve yangın söndürme gibi amaçlarla kullanılması su tüketimini azaltmaktadır. İnşaat sırasında kullanılan su da içinde boya, çimento atı̆̆ı vb. atıkları barındırmakta ve çevre kirliliğine yol açmaktadır.

Sürdürülebilir Yapı Çalışma Grubu'nun 2004 yılı raporuna (WGSC 2004) göre dünya genelinde tüketilen enerjinin \%50'si yapı kaynaklıdır. İrlanda'da yapı sektörü enerjinin \%40’nı tüketirken; Türkiye’de bu oran \%37'dir (Uluatam 2011). Avrupa Birliği'nde ise bu oran \%31'dir (Aktaş 2013). Diğer bazı kaynaklarda ise Avrupa Birliği ülkelerinde enerji tüketiminin \%40’1 ve $\mathrm{CO}_{2}$ emisyonlarının \%36'sından yapı sektörünün sorumlu olduğu belirtilmektedir (EURIMA 2015; Ayalp 2013). Enerjinin etkin kullanılması yaşam şeklinde özveride bulunulmadan, aynı kalite ve standartta ürün veya hizmet için gereken enerji miktarının azaltılması ve harcanan enerjiden en üst seviyede kazanç elde edilmesini ifade eder. Mekânların inşa edilmesi için rezervleri tükenmekte olan ve kullanımı esnasında sera gazı emisyonu yayarak çevre kirliliğine neden olan fosil yakıtlar yerine yenilenebilir enerji kaynaklarından yararlanılması önerilmektedir. Ayrıca mekânların yapı içindeki yeri ve konumunun doğru planlanması, doğal aydınlatma koşullarının sağlanması, iklimsel konfor ve enerji tasarrufunu etkileyen önemli değişkenlerdir.

Malzemeler iç mimari projelerin oluşumunda üretim teknolojisi, yapı ekonomisi, yapı fiziği ve insan konforu ile ilgilidir. Malzeme bir mekânın oluşumunda çevreye olan olumsuz etkilerin \%10-20'sini oluşturmaktadır (Sev 2009; Adıgüzel 2011). Yeryüzünden çıkarılan malzemelerin yaklaşık \%50'si yapı sektörü tarafından kullanılmaktadır (WGSC 2004). Mobilya üretiminde ise üretim maliyetinin \%91'ni hammadde oluşturmaktadır (URL-7 2017). 
Yani, mekân tasarımının bir parçası olan mobilyanın malzeme kullanımı ile yakından ilişkisi bulunmaktadır. Mekânın tasarımında kullanılan malzemelerin temini için gerekli hammadde temini, üretimi ve aşamalarında tüketilen enerji ve ortaya çıkan toksik maddeler, mekânın bakımı ve onarımı aşamalarında ortaya çıkan atıklar ve geri dönüşüm sürecini kapsamaktadır. Gömülü enerjisi (Embodied Energy) ${ }^{1}$ düşük malzemenin seçimi ile atmosfere salınan $\mathrm{CO}_{2}$ gazı azalmaktadır. Örneğin; mekânın tasarımında gömülü enerjisi yüksek alüminyum yerine geri dönüştürülmüş alüminyum kullanılması enerji tasarrufu sağlamaktadır (Crowther 2000).

Malzemeler yapay ya da doğal olsun, hammaddesini doğadan alır. İç mimari tasarımlarda kullanılan malzeme miktarının artması hem hammadde hem de enerji tüketiminin artmasına bağlı olarak çevreyi olumsuz etkilemektedir. Bu nedenle iç mimari tasarımlarda malzeme kullanımında miktar ve çeşitliliğinin azaltılması hammadde ve enerji kullanımına bağlı olarak doğal kaynak tüketimini azaltacaktır. Yerel malzeme seçimi de ulaşım için enerji gerektirmemesi ve yapının çevresel koşullara uyumu açısından önemlidir. İç mimari tasarımlarda yerel malzeme kullanımı mekânda toksik madde oluşumunu önleyerek iç mekân hava kalitesine olumlu katkı sağlamaktadır. İç mekânda malzeme seçimi ve kullanımında insan sağlı̆̆ını dikkate alarak yapılan tasarımlar "Yapı Biyolojisi”" 2 araştırmalarını gerektirir. Bir başka yöntem de geri dönüştürülebilir ve geri döndürülmüş malzeme kullanımıdır. Böylelikle faydalı ömrünü tamamlamış malzemeler mekânlarda yeniden kullanılmakta ve atık miktarı azaltılmaktadır. Örneğin; ahşap, cam, beton, alüminyum gibi malzemeler geri dönüştürülerek kullanılabilir. Ya da atıkların dönüştürülmesi ile elde edilen malzemeler kullanılabilir. Plastik, kâğıt, pet şişe, tarım atıkları gibi atıklar geri dönüştürülerek yapı malzemeleri elde edilmektedir. Örneğin; Kobe Depremi sonrasında geri dönüştürülmüş kâğıttan depremzedeler için geçici barınaklar yapılmıştır.

\subsection{Atıklar}

İç mimari işler ile çevre arasındaki ilişkinin bir başka yönü de atıklardır. Ahşap panel, mobilya gibi ürünlerin üretiminde ortaya çıkan atıklar Avrupa Atık Kataloğunda ve Tehlikeli Atıklar Kontrol Yönetmeliği’nde tehlikeli atık olarak tanımlanmıştır. Türkiye Odalar ve Borsalar Birliği'nin raporuna göre her yıl 1,545,656 $\mathrm{m}^{3}$ ahşap Türkiye'de işlenmekte ve atık sorunu oluşmaktadır. Her $\mathrm{m}^{3}$ ahşabın işlenmesinde 64 ila $1200 \mathrm{lt}$ arası atık su ortaya çıkmaktadır. EPA'ya göre ortalama atık su üretim oranı işlenmiş odunun 174 L/m³'üdür (URL-8 2017). Araştırmalara göre bir mobilya fabrikasında üretimde çıkan katı atık miktarı toplam atığın \%30'udur. Türkiye'de yıllık mobilya imalatı da $149.265 \mathrm{~m}^{3} /$ yıldır (TTGV 2010). Bu rakamlardan da anlaşılacağı üzere mekânın ve mekânı oluşturan elemanların oluşumunda ortaya çıkan atık miktarı önemli derecede fazladır (Şekil 6 ve 7). Bir iç mimari tasarım ürünü olarak mobilya, kapı, pencere, panel gibi donatılar da mekânı oluşturan diğer öğeler gibi yaşanabilir bir çevre için önemli konulardır. Genellikle bu mekân donatılarının oluşturduğu olumsuz çevresel etkiler hammadde kullanımı, üretim ve kullanım sırasında ve sonrasında oluşmaktadır. Bu öğelerin çoğunun yapımı ve kullanımında malzeme- hammadde ve enerjiye ihtiyaç duyulmakta ve üretimlerinde emisyonlar açığa çıkmaktadır. 25755 Sayılı Resmi Gazete 'de yeniden düzenlenerek yayınlanan “Tehlikeli Atıkların Kontrolü Yönetmeliği'nde tehlikeli atık listesinde yer alan mobilya ve mekân donatıları bünyelerinde VOC (uçucu organik bileşikler) olarak isimlendirilen benzen, formaldehit, tolüen gibi maddeleri içerdiklerinden tehlikeli atık olarak kabul edilmektedir (Demirarslan ve Demirarslan 2008).

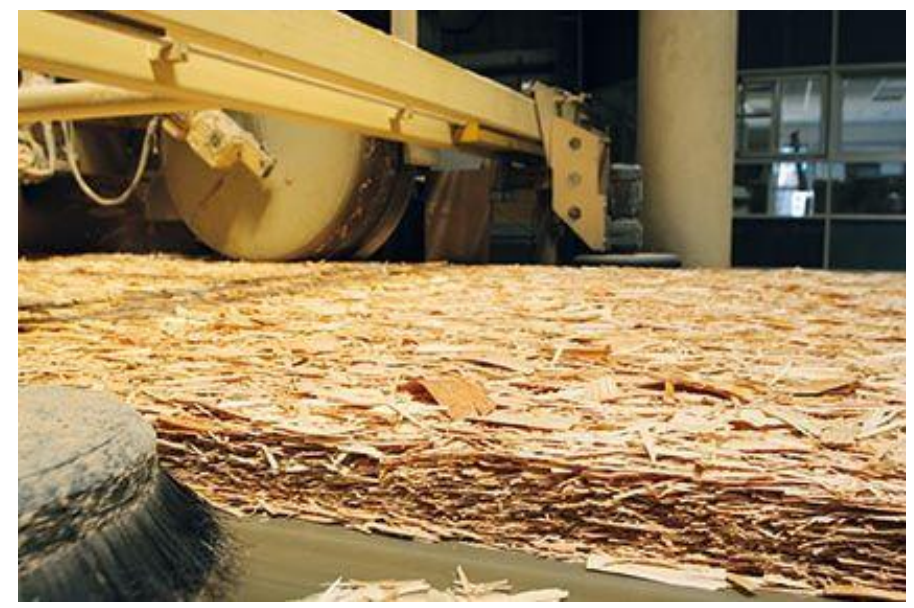

Şekil 6: Mobilya fabrikasında çıkan ağaç atığı - talaş (URL-9 2017)

\footnotetext{
${ }^{1}$ Gömülü enerji: Bir malzemenin çıkarımı ve üretimi için gerekli enerjidir. Bu enerji türü hammadde temini, üretim, nakliye, makine, alt yapı vb. tüm üretim işlemleri için gerekli enerjidir.

${ }^{2}$ Yapı biyolojisi: Yapı biyolojisi, insan ile yapılaştı̆̆l çevre arasındaki bütünsel ilişkilerin öğretisidir. Yapıların, iç mekân ve ortamların insan sağlı̆̆ına olan etkilerini inceleyen bilim dalıdır.
} 


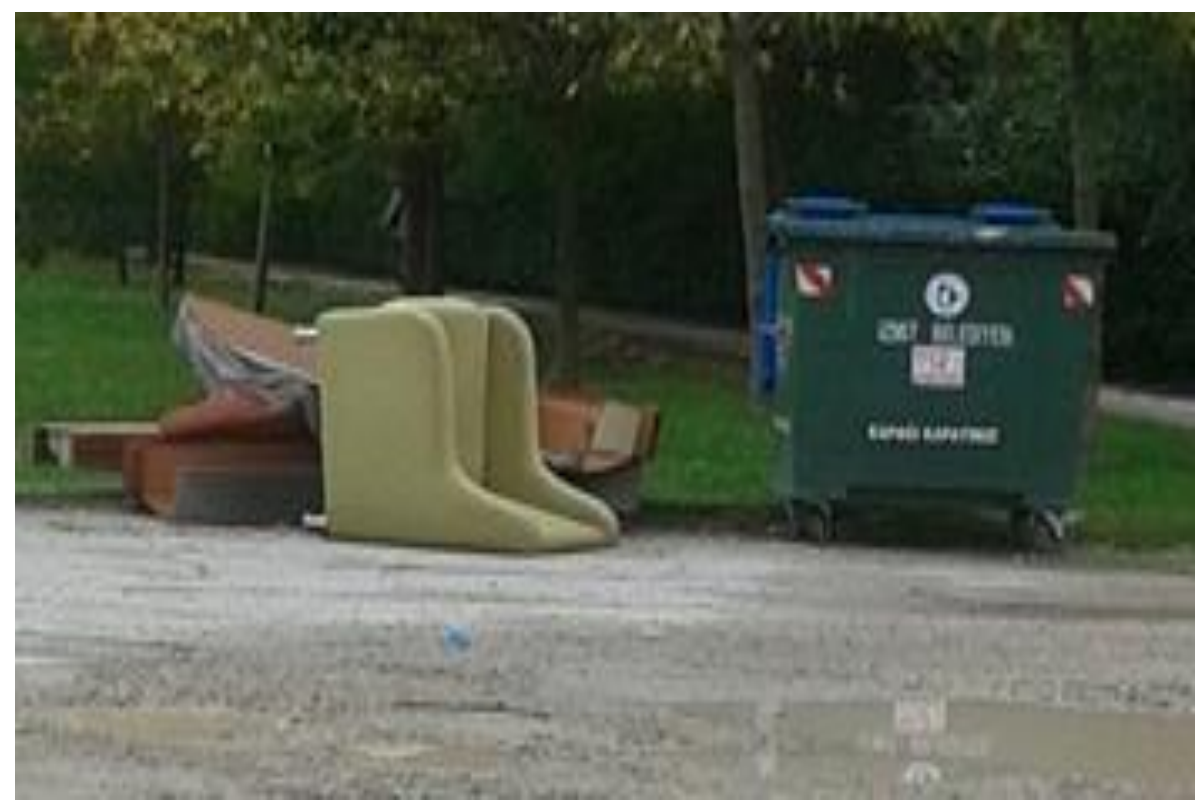

Şekil 7: Kullanım ömrü dolan ve atık haline gelen mekân öğesi mobilya (Demirarslan ve Demirarslan 2016)

İnşaat yıkıntı ve atıkları da çevreye zarar vermektedir. Kentsel atıkların \%13-30’luk gibi önemli kısmını inşaat/yıkıntı atıkları oluşturur (Fırat ve Akbaş 2015). İnşaat ve yıkıntı atıkları "evsel atık" olarak nitelendirilmekte olup; bunların kompost olması da imkânsızdır. Bu yüzden hacim olarak yer işgal etmektedirler (Şekil 8). Avrupa'da II. Dünya Savaşı'ndan sonra inşaat ve yıkıntı atıklarıyla ilgili çalışmalar başlatılmış olup; küreselleşme ile hız kazanmıştır. Avrupa ülkelerinde inşaat /yıkıntı ve onarım- bakım çalışmaları sırasında yıllık 175-370 milyon ton veya 0,5-1 ton /kişi/yıl inşaat/yıkıntı atığı oluştuğu tahmin edilmektedir (Firat ve Akbaş 2015). Avustralya'da atıkların \%75'ni inşaat atıkları oluşturmaktadır (Crowther 2000). Çevre ve Şehircilik Bakanlığı Çevre Yönetimi Genel Müdürlüğü Atık Yönetimi Başkanlığı tarafından Türkiye'de 45 milyon ton inşaat/ yıkıntı atığ 1 miktarının kentsel dönüşüm ile birlikte ilk 3 yıl boyunca yıllık 10 milyon ton, geri kazanılacak miktarın da yıllık 6 milyon ton olacağı hesaplanmıştır (URL-10 2017). Kentsel dönüşüm kapsamında şimdiye dek 88 bin birim y1kıldığı göz önünde bulundurulursa çıkan atık miktarının ne kadar fazla olduğu da ortadadır (URL-11 2017). Özellikle ülkemizde kentsel dönüşüm sürecinde yapılan bina yıkımları sırasında ortaya çıkan asbest atıkları önemli bir tehdit oluşturmaktadır. Bu süreçlerde gerekli önlemler alınmazsa gelecekteki 20 yıl boyunca asbestten kaynaklanan sağlık sorunlarının devam edeceği düşünülmektedir (Taygun 2016).

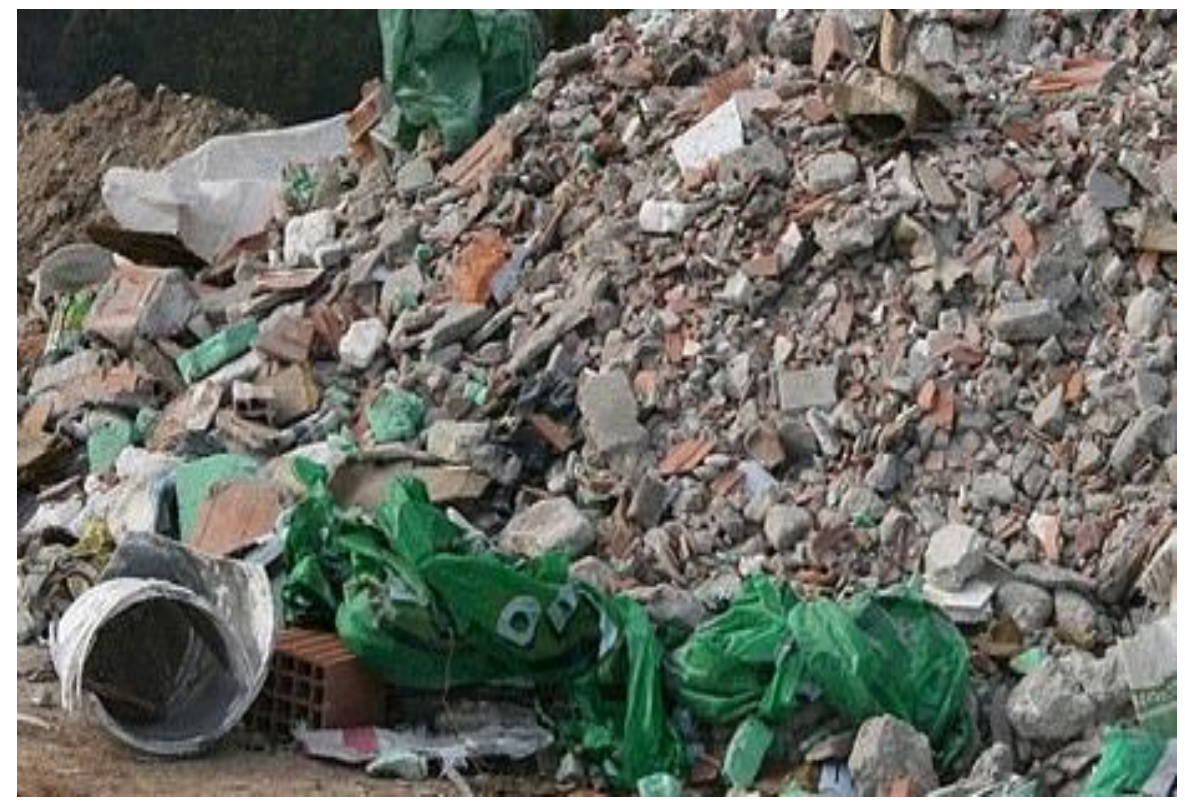

Şekil 8: Kentsel dönüşüm çalışmaları ve inşaat atıkları - molozlar (URL-12 2017) 


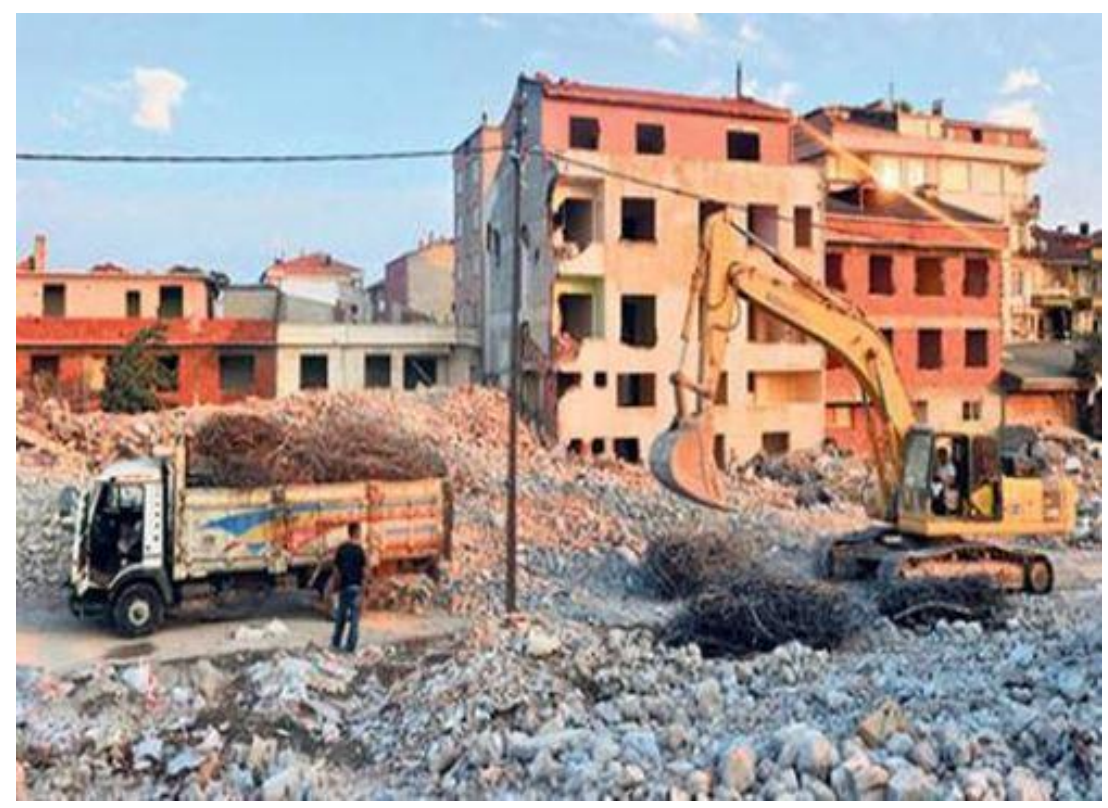

Şekil 9: Kentsel dönüşüm çalışmaları ve inşaat atıkları - molozlar (URL-13 2017)

Türkiye'de son yaşanan depremlerden sonra başlatılan kentsel dönüşüm çalı̧̧aları kapsamında ciddi anlamda inşaat/yıkınt//tadilat atığı çıkmaktadır (Şekil 9). Ayrıca, değişen iç mimari trendler, kullanım ihtiyaçları gibi gereksinimler de değişime uğrayan iç mekânlardaki tadilatlar sonucu da büyük miktarda atık çıkmaktadır (Şekil 10). Türkiye'de inşaat atıklarının doğal çevreye zarar verecek şekilde biriktirilmesinin önüne geçilmesi, bu malzemelerin geri dönüşümünün sağlanması amacıyla, 18 Mart 2004 tarih ve 406 sayılı Resmi Gazete'de "Hafriyat Toprağı, İnşaat ve Yıkıntı Atıklarının Kontrolü Yönetmeliği” yayınlanmıştır.
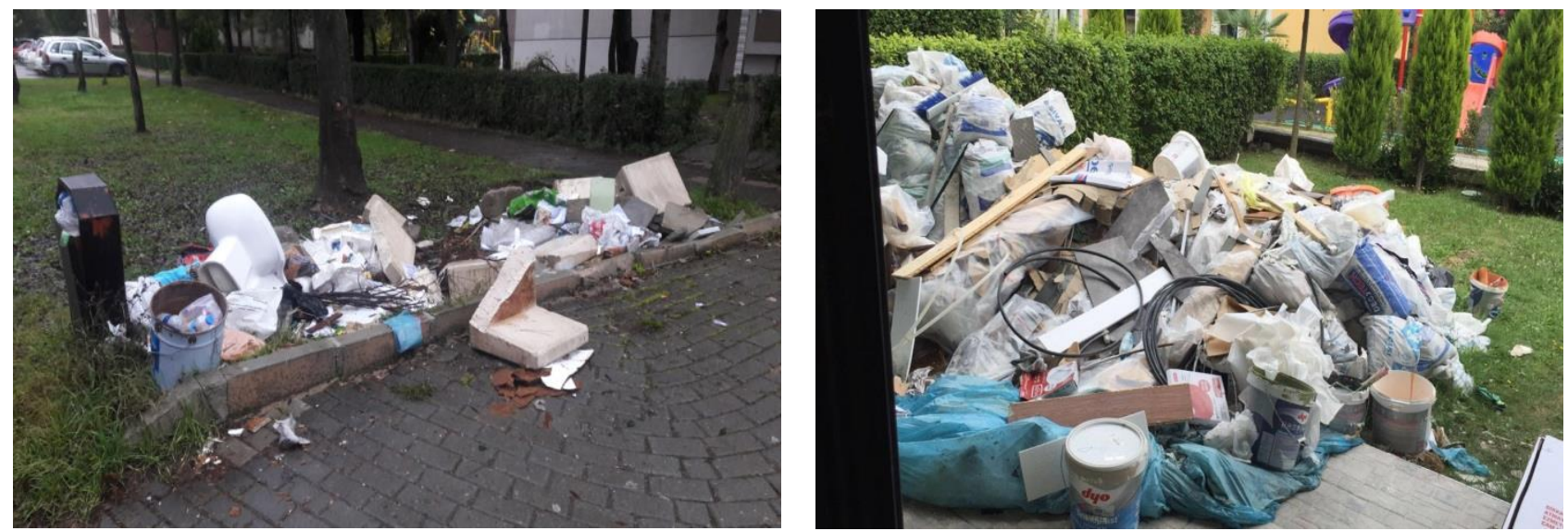

Şekil 10: Değişen iç mimari trendler, kullanım ihtiyaçları gibi gereksinimler de değişime uğrayan iç mekânlardaki tadilatlar sonucu da büyük miktarda atık çıkmaktadır.

$\mathrm{Bu}$ nedenle, Uluslararası Yapı Sektöründe Gelişme ve Araştırma Konseyi (International Council for research and Innovation in Building Construction) CIB Task Group 39 tarafindan da bu gruba dâhil ülkelerde (Avustralya, Almanya, İsrail, Japonya, Hollanda, Norveç, İngiltere, Amerika Birleşik Devletleri) tasarımcıların yıkmadan, mümkün olduğu kadar fazla malzemeyi, çevreye en az zarar verecek şekilde yeniden kullanması öngörülmektedir. CIB Task Group 39 binaların yıkımını gerektirmeyen ve kolay sökülebilecek şekilde tasarlanmasını teşvik etmektedir (Kibert ve Chini 2000; Elias Özkan 2003). Ancak Türkiye'de henüz geri kazanılmış inşaat malzemelerinin onaylanmaması ve Bayındırlık Bakanlığı'nca hazırlanan pozlar ve mevzuatlar geri kazanılmış malzemelere uygun olmadığı için bu tür çalışmalar yapılamamaktadır.

Y1kılan binalardan kurtarılamayan malzemelerin başında beton ve fayans gelmektedir. Bu malzemelerin Türkiye'de moloz olarak döküm yerlerine atılırken; gelişmiş ülkelerde kırılıp agrega olarak kullanıldığı görülmektedir. Örneğin; Adana Depremi sonrasında çıkan moloz Seyhan Irmağı'na boşaltılmıştır (Elias Özkan 2003). Ayrıca bir iç mimari tasarım öğesi evsel katı atıktır. Türkiye İstatistik Kurumu'nun yapmış olduğu araştırmalara göre Türkiye'de kişi başına evsel katı atık miktarı yılda $187 \mathrm{~kg} / \mathrm{y} 1 \mathrm{l}$ iken; yıllık toplam katı atık miktarı 12 milyon ton olarak belirlenmiştir 
(Demirarslan ve Demirarslan 2008). Bunların \% 12'si geri dönüştürülebilir atıklar olup; mekân donatılarının atık olarak bertaraf edilmeleri ya da geri dönüştürülerek yeniden kullanımları çevre mühendisliği ve iç mimarlık disiplinlerinin temellerini ilgilendiren bir konudur. Mekânlar ve mekânlarda kullanılan donatıların bir kullanım ömrü olup; ömrü tükendikten sonra bunların bertarafı ya da yeniden kullanımında enerji kullanımı söz konusu olmaktadır.

Yukarıda da tanımını yaptığımız gömülü enerji iç mimari uygulamalarda ayrıca önem taşımaktadır. Örneğin; çok katlı bir ofis binasında yeniden tasarım söz konusu olduğunda yapının taşıyıcı sistemi ve döşeme plakları toplam gömülü enerjinin \%60’nı, kaldırılan kaplama, iç duvar gibi öğeler de \%40’nı oluşturmaktadır (Crowther 2000). Çıkarılan öğelerin tekrar kullanımında enerji tasarrufu çok yüksektir. Bu nedenle mekânın tasarımında mekân ve mekânı oluşturan elemanların ömürlerinin bilinmesi enerji tasarrufu açısından önem taşımaktadır.

Tablo 1: Mekân ve mekânın tasarımında kullanılan donatı ve malzemelerin kullanım ömürleri (Adalberth 1996; Crowther 2000; Kurokawa 1997; Chini 2001)

\begin{tabular}{|c|c|}
\hline Mekan, donatı ya da malzeme & Ömrü (yıl) \\
\hline Doğal çevre & $15000 \mathrm{y} 1 \mathrm{l}$ \\
\hline Plan düzeni & Ticari yapılar 3 yıl, Konut 30 yıl \\
\hline Mutfak-Banyo & $3-15$ y1l \\
\hline Oturma odas1 ve yatak odas1 & $5-8$ y1l \\
\hline Mağaza reyonu & 6 ay \\
\hline Dükkân & 5 y1l \\
\hline Mağaza- ofis-okul & $10 \mathrm{y} 11$ \\
\hline Konut & $25 \mathrm{y} 11$ \\
\hline Kamu binas1 & $125 \mathrm{y} 1 \mathrm{l}$ \\
\hline Kültür yapıs1- anıt (kâgir yap1) & $625 \mathrm{y} 1 \mathrm{l}$ \\
\hline D1ş ve iç duvarlar, hatıllar, temel, yalıtım & 50 yil \\
\hline Yer döşemeleri (mermer, granit, seramik vb.) & $50 \mathrm{y} 11$ \\
\hline Havalandırma Kanalları & $10-50 \mathrm{y} 1 \mathrm{l}$ \\
\hline Su Boruları ve Elektrik Kabloları & $10-50$ y1l \\
\hline Asansör, hidrolik sistem & $10-15$ y1l \\
\hline İç ve dış cephe kaplaması & $20 \mathrm{y} 11$ \\
\hline Ahşap paneller & $30 \mathrm{y} 11$ \\
\hline Kap1 ve Pencereler & $30 \mathrm{y} 11$ \\
\hline Mobilya & $5-7$ y1l \\
\hline Dolaplar ve Mutfak Dolapları & $30 \mathrm{y} 1 \mathrm{l}$ \\
\hline Kiremitler ve yağmur olukları & $30 \mathrm{y} 11$ \\
\hline Beyaz eşya & $12 \mathrm{y} 11$ \\
\hline Halilar & $17 \mathrm{y} 1 \mathrm{l}$ \\
\hline Boya ve duvar kâğıdı & $10 \mathrm{y} 11$ \\
\hline
\end{tabular}

\section{Mekânın ömrü / donatı ya da malzemenin ömrü - 1 = Donatı ya da malzeme içi gerekli değişim miktarı}

Mekan ve donatı elemanı ömrü ve bunların değişim miktarlarının hesaplanmasında yukarıdaki formül (Formül 1) esas alınarak gelişmiş ülkelerde mekânda kullanılan donatı, malzeme değişim miktarına göre enerji kullanımları, atık yönetimi çalışmaları gerçekleştirilmektedir (Adalberth 1996). Ancak burada dikkat edilmesi gereken husus özellikle iç mekânda malzeme ve donatıların iki tür ömürlerinin bulunmasıdır. Genelde kullanım ömrü mekân, donatı ve malzemenin fiziksel ömrünü tamamlaması olarak bilinmekle beraber; özellikle iç mekânın tasarımında günün modasına uygun yeni tasarımlar ile birlikte mekân, donatı ve malzemenin estetik ömrünü tamamlaması böylece kaynak kullanımı sarfiyatı ve atıkların ortaya çıkması söz konusu olmaktadır.

\subsection{Gürültü Kirliliği}

Gürültü kirliliği iç mimari tasarımlar ile çevre mühendisliği arasındaki bir başka ortak paydadır. Gürültünün, toplumun büyük ve önemli bir bölümüne verdiği zarar, gerçekten çok yönlü ve sanıldığından daha önemlidir. Mekânın ses yönünden insan sağlığını etkilemeyecek düzeyde tasarlanması iç mimarın görevi iken; gürültü kirliliğinin ölçümü ve etkilerinin saptanması çevre mühendisliğinin çalışma kapsamındadır. Ayrıca mekânların inşası sırasında kullanılan araçlar gürültü kirliliğine neden olmaktadır. "Türkiye'de Çevresel Gürültünün Değerlendirilmesi ve Yönetimi Yönetmeliği” kapsamında dış ortam ve iç mekânda gürültü kirliliğinin önlenmesine ilişkin tedbirlerin alınması sağlanmıştır. Değişik ülkelerde yürürlükte olan yönetmeliklere göre gürültü kirliliği sınırı çok ufak değişiklikler gösterir. Genelde, günde 8 saatlik bir süre için, bu sınır 85-90 dB(A)'dır (URL-14 2017). Gürültüyü oluşturan frekansların belli özel durumları, örneğin ses enerjisinin, bir ya da birkaç frekansta toplanmış olması, zararlılığı arttırmaktadır. Gürültünün zararı günlük doz ile orantılıdır. Doz, gürültü düzeyi ile sürenin çarpımı gibi düşünülebilir. Yukarıda da belirtildiği üzere Uluslararası Standartlar Örgütü (ISO) 8 saat süreyle 85-90 dB(A) düzeyinde bir 
gürültüyü, günlük maksimum doz olarak belirlemiştir. Bu değerin üzerindeki dozlar, dozun yüksekliği oranında zarar verir. Mekânın tasarımında gürültü kirliliğinin hesaplanması ise, gürültü denetimi projesinin ve mekânın kullanım amacına göre, zararlı etki bakımından günlük dozun altına inilmesi, ya da belli frekanslar için rahatsızlık sınırlarının altına inilmesini sağlamak üzere, ulusal yönetmeliklerden ya da uluslararası kabullerden ve ölçme sonuçlarından yola çıkarak, alınacak önlemleri belirlemeye yönelik olarak yapılır. Gürültü denetiminde plan, ölçmeler ve hesaplar bir bütündür. Bunlar gereği gibi yapılmazsa, mekân insan sağlığını tehdit edecek bir hale gelir ve ayrıca boş yere zaman ve para harcanacağı unutulmamalıdır (URL-14 2017).

29/6/2001 tarihli ve 4708 sayılı Yapı Denetimi Hakkında Kanun ve 8/9/2002 tarihli ve 24870 sayılı Resmî Gazete'de yayımlanan Yapı Malzemeleri Yönetmeliğindeki (89/106/EEC) esasları sağlamak koşulu ile kat mülkiyeti esasına göre birden çok malikin bulunduğu yapılarda yapı elemanlarında (duvar, döşeme, tavan, merdiven evi ve diğer) ses yalıtımının yapılması zorunludur. Mekânda gürülttü kontrolünün daha tasarım aşamasında sağlanabilmesi için gürültüye duyarlı ve gürültü kaynağı olan faaliyet alanlarının bilinmesi gerekir ve bu alanlar için mühendislerce öngörülen gerekli ses değerleri dikkate alınmalıdır (Tablo-2).

Tablo 2: Yapılarda Gürültü Kaynağı Olan Faaliyet Alanı ve Etkilenen İç Alanlar (Gürültüye Duyarlı Faaliyet Alanı) (Çevresel Gürültünün Değerlendirilmesi ve Yönetimi Yönetmeliği - Madde 31)

\begin{tabular}{|c|c|c|}
\hline $\begin{array}{c}\text { Yapı Tipleri ve İç } \\
\text { Mekân Gürültü } \\
\text { Düzeyi Sınır } \\
\text { Değerleri }\end{array}$ & Gürültüye Duyarlı Faaliyet Alanı & Gürültü Kaynağı Olan Faaliyet Alanı \\
\hline $\begin{array}{c}\text { Konutlar (35- } 60 \\
\text { desibel arası) }\end{array}$ & $\begin{array}{l}\text { Yatak odaları, oturma, yemek, çalışma, müzik odaları, } \\
\text { doktor evlerinde muayene ve bakım odaları, dinlenme } \\
\text { terasları ve avlular. }\end{array}$ & $\begin{array}{l}\text { Sirkülasyon ve tesisat alanları, otoparklar, garajlar, } \\
\text { çamaşırlık, asansörler, hidrofor, merdivenler, ev atölyeleri, } \\
\text { müzik çalışma odaları, çocuk bahçeleri, spor alanları. }\end{array}$ \\
\hline $\begin{array}{c}\text { Okullar (35 } \\
\text { desibel) }\end{array}$ & $\begin{array}{l}\text { Sınıflar, okuma odaları, konferans salonları, idari mekânlar, } \\
\text { revir ve bakım odaları, laboratuvarlar, anaokullarında } \\
\text { uyuma mekânları. }\end{array}$ & $\begin{array}{l}\text { Avlular ve oyun yerleri, spor salonları, atölyeler, müzik } \\
\text { stüdyoları, mutfak ve tesisat alanları, otoparklar ve garajlar. }\end{array}$ \\
\hline $\begin{array}{c}\text { Hastaneler (25-35 } \\
\text { desibel arası) }\end{array}$ & $\begin{array}{l}\text { Hasta yatak odaları, bekleme alanları, ameliyathane, özel } \\
\text { bakım yerleri, dinlenme alanları, koridorlar ve idare odaları. }\end{array}$ & $\begin{array}{l}\text { Tesisat merkezleri, asansör ve mutfak ve servis alanları, } \\
\text { otoparklar ve garajlar. }\end{array}$ \\
\hline $\begin{array}{l}\text { İdari Yapılar (35- } \\
45 \text { desibel arası) }\end{array}$ & Çalışma mekânları. & $\begin{array}{l}\text { Gürültülü çalışma alanları, bilgisayar merkezleri, tesisat } \\
\text { merkezleri, sirkülasyon alanları, kafeterya, mutfak ve diğer } \\
\text { servis alanları, garaj ve otoparklar. }\end{array}$ \\
\hline $\begin{array}{c}\text { Ticarethaneler (45- } \\
60 \text { desibel arası) }\end{array}$ & Bürolar, satış alanları, teşhir yerleri ve lokantalar. & $\begin{array}{l}\text { Gürültülü satış alanları, oyun mahalleri, kafeteryalar, } \\
\text { otopark ve garajlar, tesisat alanları ve diğer servisler. }\end{array}$ \\
\hline $\begin{array}{l}\text { Oteller }(30-35 \\
\text { desibel arası) }\end{array}$ & $\begin{array}{l}\text { Yatak odaları, dinlenme salonları, yemek salonları, toplantı } \\
\text { salonları, idare mekânları, manzara terasları, dinlenme avlu } \\
\text { ve bahçeleri. }\end{array}$ & $\begin{array}{l}\text { Tesisat hacimleri, mutfak ve servis alanları, otopark ve } \\
\text { garajlar, açık lokantalar, diskotek, düğün salonu ve diğer } \\
\text { gürültülü eğlence ve spor alanları. }\end{array}$ \\
\hline
\end{tabular}

\subsection{Hava Kalitesi}

Mekânın tasarımında malzeme seçimi hususunda iç mimarlık ve çevre mühendisliği arasındaki ilişkinin incelenmesinde bir diğer önemli konu da iç ortam hava kalitesi ve hasta bina sendromudur. Dünya Sağlık Örgütü (WHO) tarafından yayımlanan "Sağlıklı İç Ortam Havası Hakkı" adlı raporda (WHO 2000) iç ortam hava kalitesi; hastalık riski taşımayan ve içerideki bütün insanlar için rahatlık sağlayan hava olarak tanımlanmaktadır (Fanger 2004).

İç mekânda özellikle yanlış malzeme seçimi ve uygulamaları hasta bina sendromuna neden olmaktadır. Bu amaçla mekânın oluşumunda kullanılacak malzemelerde elektro- iklimsel kirlilik oluşturmama, üretim ve uygulamada toksik gazları yaymama, düşük radyoaktivite özellikleri aranmaktadır. Örneğin; asbest lif, formaldehit buharı, VOC'lar, sigara dumanı, radon gazı iç ortam hava kalitesini belirlemektedir. Diğer yandan havasız, koku içeren ortamlar sağlıksız olmakla birlikte, kullanıcı konforunun azalmasına, çalışma performanslarının düşmesine ve çeşitli sağlık sorunlarına neden olmaktadır (Maroni vd. 1995; Salthammer 2004) . Bu nedenle yaşadığımız mekânların hem iç ortam hava kalitelerinin bozulması hem de binalardan ısınma gibi amaçlarla çıkan gazların dış hava kalitesini bozması mekânların tasarım aşamasından başlayarak alınan önlemler ve yapılan uygulamalar ile en az düzeye indirilmeye çalışılmaktadır. Mekânın içi kadar dışındaki ortam hava kalitesinin kontrolü de yine iç mimarlık ve çevre mühendisliğinin ortak konuları arasında yer almaktadır.

Dış ortam hava kirliliği de cephe kaplama malzemelerinin fiziksel ve görsel bozulmasına sebep olmakta, yapılan bakım-onarım, yenileme çalışmaları ise kaynak kullanımı açısından çevreye zarar vermektedir. Bu nedenle düşük karbonlu cephe kaplama malzemelerinin kullanımı tercih edilmektedir.

Özellikle bacalardan çıkan kurum gibi kirleticiler ile $\mathrm{SO}_{2}$ 'nin sebep olduğu zararlar ve asit yağmurları başta korozyon ve aşınma gibi hasarlara neden olmaktadır (Jacobson 2002; Demirarslan ve Demirarslan 2008). 


\section{6. Çevre Koruma Bilinci Bağlamında İç Mimari Tasarım}

Birleşmiş Milletler Çevre ve Kalkınma Komisyonu'nun 1987 yılı tanımına göre; “insanlık gelecek kuşakların gereksinimlerine cevap verme yeteneğini tehlikeye atmadan, günlük ihtiyaçlarını temin ederek, kalkınmayı sürdürülebilir kılma yeteneğine sahiptir”. Sürdürülebilir kalkınma insan ve çevre merkezli olmak üzere iki ana başlık altında değerlendirilmektedir. Doğal çevrenin korunması kadar ekonomik ve sosyal kalkınmanın birbirinden ayrılmaz parçalar olduğu kabul edilmektedir (URL-15 2017).

İnsanlar eylemleri ile çevreyi diğer canlılardan farklı bir şekilde etkiler ve olumlu ya da olumsuz olabilen bu etkinin sonucunda çevrenin niteliği değişir. Temel olarak, toplumun benimsediği değer ve kurallara göre düzenlenen insan davranışlarının ve eylemlerinin çoğunlukla doğaya ve çevre-sistemlere büyük zarar verdiği bilinmektedir. Bu eylemlerden birçoğu da mekân yani yapma çevre ile ilgilidir. Mekân insan ihtiyaçları doğrultusunda üretilen çevredir. $\mathrm{Bu}$ çevrenin üretilmesi, kullanılması ve yok edilmesi sırasındaki insan eylemleri nedeniyle daha evvelce de açıklandığı üzere büyük çoğunlukla enerji, ürün, su ve benzeri yenilenemeyen kaynaklar tüketilmekte ve çevre kirletilmektedir (Darçin 2014).

Ortaya çıkan çevre sorunları günümüz toplumlarında her alanda olduğu gibi iç mimarinin en büyük problemlerinden birisini oluşturmaktadır. Mekânları tasarlayanlar tasarım, uygulama ve kullanım aşamalarında doğaya aşırı müdahale edilmesi, atık meydana getirilmesi ve doğal kaynakların sorumsuzca tüketilmesi nedeniyle hızla artan çevre sorunlarından sorumlu tutulmaktadır. Bu nedenle ekoloji ve sürdürülebilirlik kavramlarının yardımıyla çevre dostu mekân ve mekân elemanı tasarımları ve uygulamaları geliştirilmeye yönelik çalışmalar yapılmaktadır. Bu tartışmanın içinde mevcut mekânların ekolojik dönüşümü de önemli yer tutmaktadır. Yapılı çevreyi şekillendiren diğer tasarım disiplinlerinde olduğu gibi iç mimarlık disiplinine de önemli görevler yansımıştır.

Tasarım temelli disiplinlerde çevreci anlayışlar 1970'li yıllarda sosyo-politik bir söylemle ortaya çıkmıştır. Bu yıllarda "yeşill" kavramı ile tasarımın yeşillenmesi çabaları başlamıştır. 1980’li yıllardan itibaren yapılarda daha önce de tanımları yapıldığı üzere enerji tasarrufunun yanı sıra mekânın sağlıklaştırılmasına dikkat edilerek "yeşil tasarım” ve “ekolojik tasarım” kavramları ön plana çıkmıştır ve tüm bunlar "sürdürülebilir iç mimari” kavramını oluşturmuştur.

Sürdürülebilir mekân tasarımı dolayısıyla sürdürülebilir iç mimari, sadece teknik, mimari, sosyal ya da ekonomik bir bina yapım süreci olmayıp; uzun vadeli bakış açılarına verilen önemi güçlendirerek mekânsal çözümlemeler üretmeyi hedefleyen bir tasarım anlayışıdır (Özmehmet 2007; Sev 2009). Çevre ile uzlaşmayı amaçlayan bu tasarım anlayışı, doğal kaynakları koruyan, kültürel ve tarihsel kaynakları benimseyen bir tasarım ürünüdür.

Ekolojik mekân tasarımı ise; doğa ile barışık ve doğaya en az zarar verecek tasarımları gerçekleştirmek olarak tanımlanmaktadır. Ekolojik dengeyi korumak ve doğal kaynakların hesaplı tüketilmesini sağlamak, tasarımcıları ve yatırımcıları ekolojik mekânlar tasarlama konusunda yönlendirmektedir (Yeang 2012).

Yeşil iç mimarlık kavramı da insanların sağlığı, çevre ve enerji tasarrufu için neyin iyi ve neyin kötü olduğu ile ilgilidir. Yeşil iç mimarlık, mekânın tasarımında enerji ve su tasarrufunu sağlamak ve sera gazı emisyonlarını azaltmanın yollarını bulmak, iç mekânı zehirli kimyasallardan arındırmak, çevre dostu malzemeleri kullanarak, bir binanın iç mekânının bütün yönlerini, parçalarını incelemek ve iyileştirmekle ilgili tüm konuları kapsamaktadır (Dennis 2010). Tasarlanan mekânlarda sürdürülebilirliğin değerlendirildiği BREEAM (Building Research Establishment Environmental Assessment), Leed (Leadership in Energy and Environment Design) gibi sertifikasyon sistemleri geliştirilmiştir.

Tasarım temelli disiplinlerin içinde çevreci yaklaşımın en geç geliştiği disiplin iç mimarlıktır. Faulkner (2007) bağımsız olarak en geç iç mimarlık disiplininin çevreci yaklaşım konusunda organize olduğunu bildirmiştir. Faulkner bu durumu iç mimarlığın uzun yıllardır var olmasına rağmen, meslek olarak uygulanmasının ve eğitiminin geç tanınması ile açıklamaktadır. Çevreci yaklaşımlar iç mimarlık disiplinine geç yansımış olsa da yapılan ampirik çalışmalar, yayınlar, geliştirilen teknolojiler, malzemeler ve yöntemler ile çevreye duyarlı iç mimari tasarım ve uygulamalar geliştirilmektedir. Sürdürülebilirlik çalışmaları günümüzde fütüristik-gelecekçi mekânların tasarımlarında tasarımcıların mühendisler ile ortak çalışmalar yaptığı mekân tasarımı örneklerini desteklemiştir (Şekil 11-16).

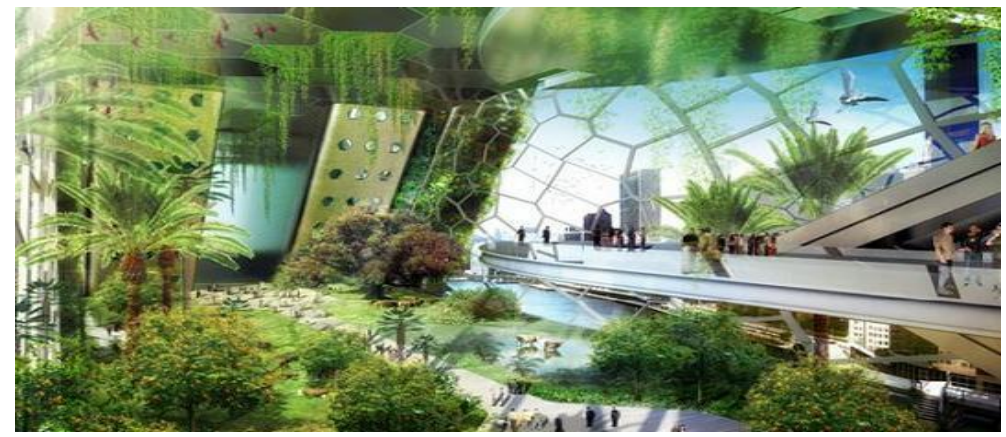

Şekil 11: "Dragon Fly" ekolojik şehri New York için tasarlanmıştır ve 132 katı "Dragon Fly" ekolojik şehrinde sığır ve kümes hayvanları, 28 farklı tarım ürünü, güneş enerjisi ve yağmur suyu ile yetiştirilmesi amaçlanmıştır (URL-16 2017) 


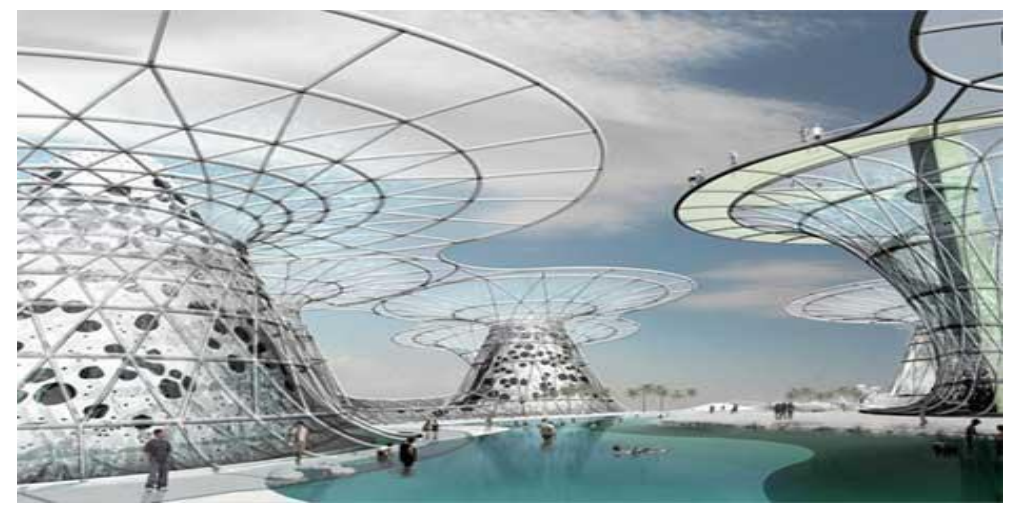

Şekil 12: "No Man's Lan" projesi ada ağlarından meydana geliyor ve havadaki su moleküllerinden saf içme suyu elde eden, yapay bir takımada ve bu adada yer alan sürdürülebilir mekânlardan oluşuyor (URL-16 2017)

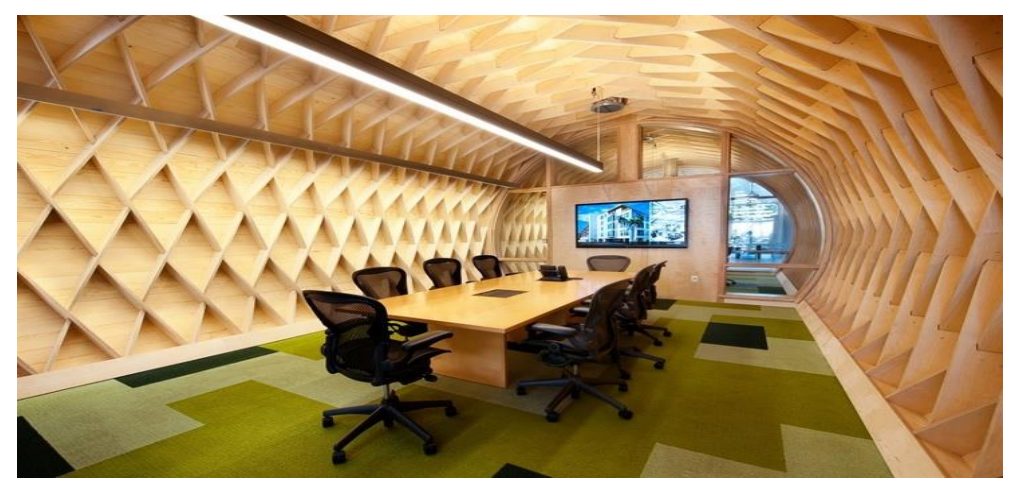

Şekil 13: Sürdürülebilir iç mimari örneği- ekolojik malzeme kullanımı (URL-17 2017)

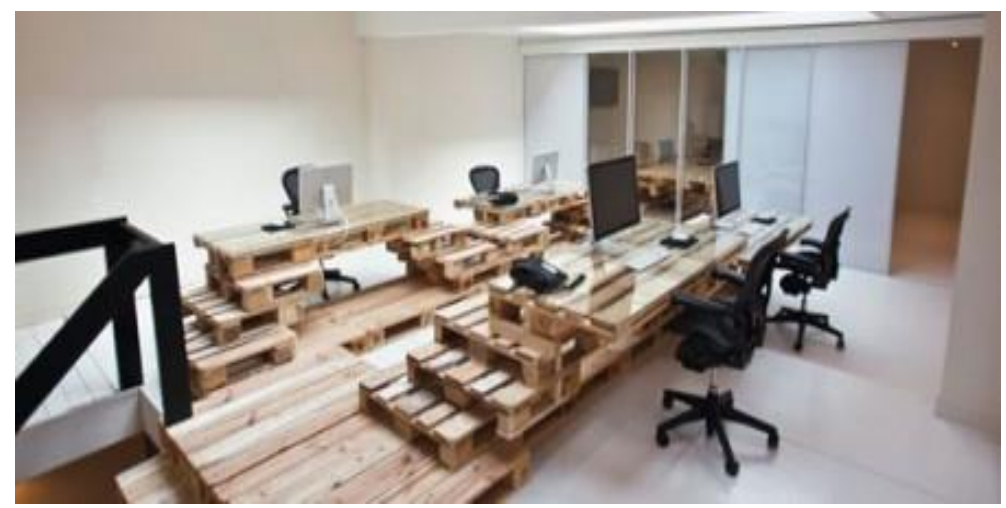

Şekil 14: Atık malzemenin ofis iç mekânının tasarımında kullanımı ve bir geri dönüşüm uygulaması (URL-18 2017)

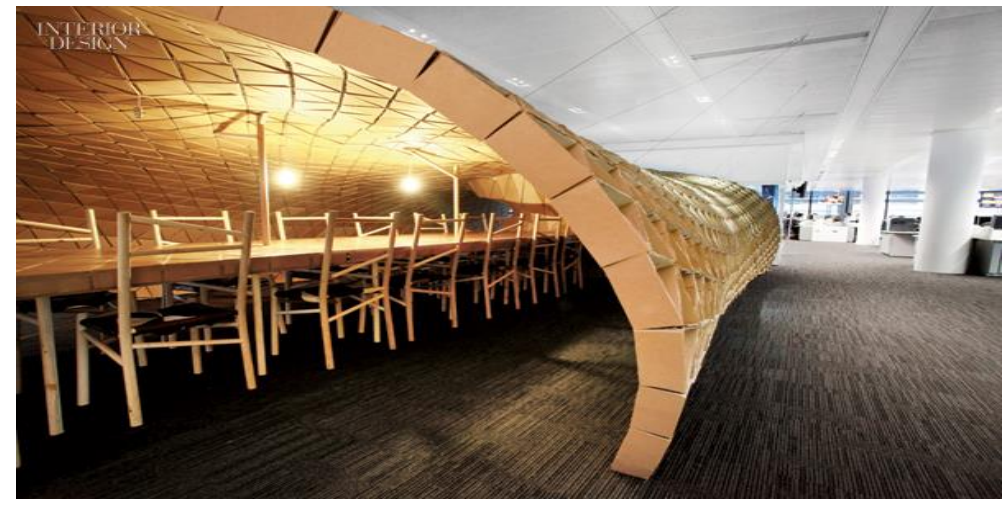

Şekil 15: Geri dönüştürülmüş atık kartonlardan iç mekân tasarımı örneği (URL-19 2017) 


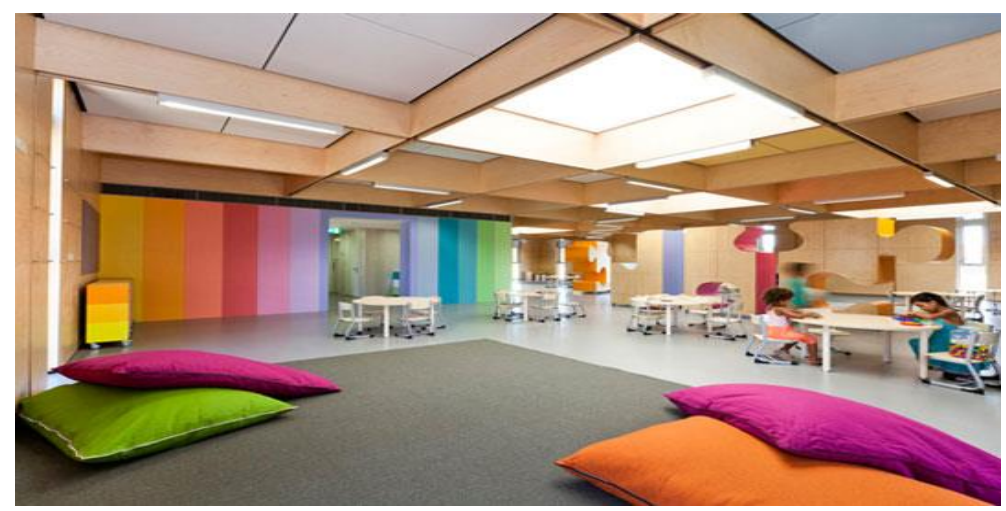

Şekil 16: Ekolojik malzeme kullanımı ve çevreci yaklaşımlar ile tasarlanan bir anaokulu iç mekânı (URL-20 2017)

Özetle, sürdürülebilir-çevreye duyarlı iç mimarlık mekân tasarımının çevreye ve kullanıcısına olan negatif etkilerinin minimize edilmesi ve mekânın tasarım, uygulama, kullanım süreçlerinde çevresel, ekonomik ve sosyal aşamalarda optimizasyon sağlanması olarak tanımlanır (Kang 2004; Kang ve Guerin 2009; Adıgüzel 2011). İç mimarlık uygulamaları da yeniden yapı inşa etmek yerine, çoğunlukla mevcut yapıların yeni işlevler kazandırılarak kullanılmasına imkân sağlaması nedeniyle çevreci yaklaşımı bünyesinde barındırır. CIB tarafından 1999 yılında yayınlanan "Sürdürülebilir Konstrüksiyon" başlıklı raporda da sürdürülebilir mekânların temel ilke ve hedefleri üç ana başlık altında toplanmıştır:

- Kaynak kullanımı

- Çevre ve doğal ortamın iyileştirilmesi

○ Sosyo- ekonomik, kültürel ve politik gerçeklerin gözetilmesi (Altuncu 2010).

Bir mekân sadece kullanıcıları ve yakın çevresini değil; sonuçta uzun vadede ekolojik dengeyi etkilemektedir. Araştırmacılar tarafından (Ehrlich ve Holdren 1971; Sylvan ve Bennet 1994) çevresel etkileri aşağıda verildiği gibi formüle edilerek (Formül 2) esasen insanın temel ihtiyacı olan iç mekândan başlayarak kent ve bölge ölçeğine büyüyen mekân kavramının önemi vurgulanmıştır. Formülden de anlaşılacağı üzere mekân ihtiyacı nüfus artışı ile artış gösteren, yapımı, uygulanması ve kullanımı ile bir tüketim olgusu olup; teknoloji ile desteklenmektedir. Bu üç olgu bir araya geldiğinde ise çevresel etki oluşturmaktadır. Mekânlar ana enerji kaynaklarından biri olarak verimli alanların yok olmasına, doğal kaynakların tüketilmesine, kirliliğe ve karbon emisyonlarına neden olmaktadırlar.

$I=P \times A \times T$

I= Çevresel etki, $P=$ Nüfus, $A=$ Tüketim, T= Teknoloji (Raven 2001)

Görülmektedir ki; sürdürülebilir, ekolojik ya da yeşil iç mimari, her üç kavram da birbirine çok yakın kavramlar olup; mekânın çevreye zarar vermeyecek şekilde tasarımı, yapımı ve kullanımı ile ilgilidirler. Dolayısıyla mekânın tasarımında çevre mühendisliği disiplininden destek almak günümüzde bir zorunluluk haline gelmiştir.

\section{Sonuç}

Hızla gelişen teknolojiyle birlikte günümüzde tüketim toplumlarının çevreye verdiği zararların büyük oranda olması nedeniyle, 21. yüzyılda çeşitli disiplinlere (çevre mühendisliği gibi) paralel olacak bir şekilde yapılı çevrenin sürdürülebilirliği mekân tasarımını oluşturan disiplinler tarafından da sorgulanmaktadır.

Sonuç olarak görülmektedir ki; bina çevresinin, mekânların ve malzemelerin, iç mimari uygulamaların insan ve çevre sağlığı üzerindeki etkilerinin incelenmesi gerekir. Bir tasarım disiplini olan iç mimarlık ile bir mühendislik disiplini olan çevre mühendisliği arasındaki ilişki ilk bakışta uzak bir ilişki gibi görülse de; yapılan açıklamalardan da anlaşılacağı üzere iki disiplin arasında aslında yakın bir ilişki bulunmaktadır.

Bu ilişki mekânın tasarımında;

○ Kaynak kullanımı

- Atıklar

○ Gürültü ve

- Hava kalitesi konularında ortak paydalar oluşturmaktadır.

Bir mekân sadece kullanıcıları ve yakın çevresini değil; sonuçta uzun vadede ekolojik dengeyi etkilemektedir. Bir tasarım ürünü olan mekânın çevreye olan etkisinin \%70’i daha tasarım aşamasında oluşmaktadır. Mekân üretim, tüketim ve bertaraftan kaynaklanan çevresel zararın somutlaşması olarak tanımlanmaktadır. Çevre koruma bilinci bağlamında iç mekan tasarımı da mekân tasarımının çevreye ve kullanıcısına olan negatif etkilerinin minimize edilmesi ve mekânın tasarım, uygulama, kullanım süreçlerinde çevresel, ekonomik ve sosyal aşamalarda optimizasyon 
sağlanması olarak tanımlanır. Dolayısıyla iç mimarlık günümüzde sadece tek bir disiplinin çalışma alanları ile sınırlı kalamayacaktır. Disiplinler arası bir çalışmaya gereksinim duyulmaktadır.

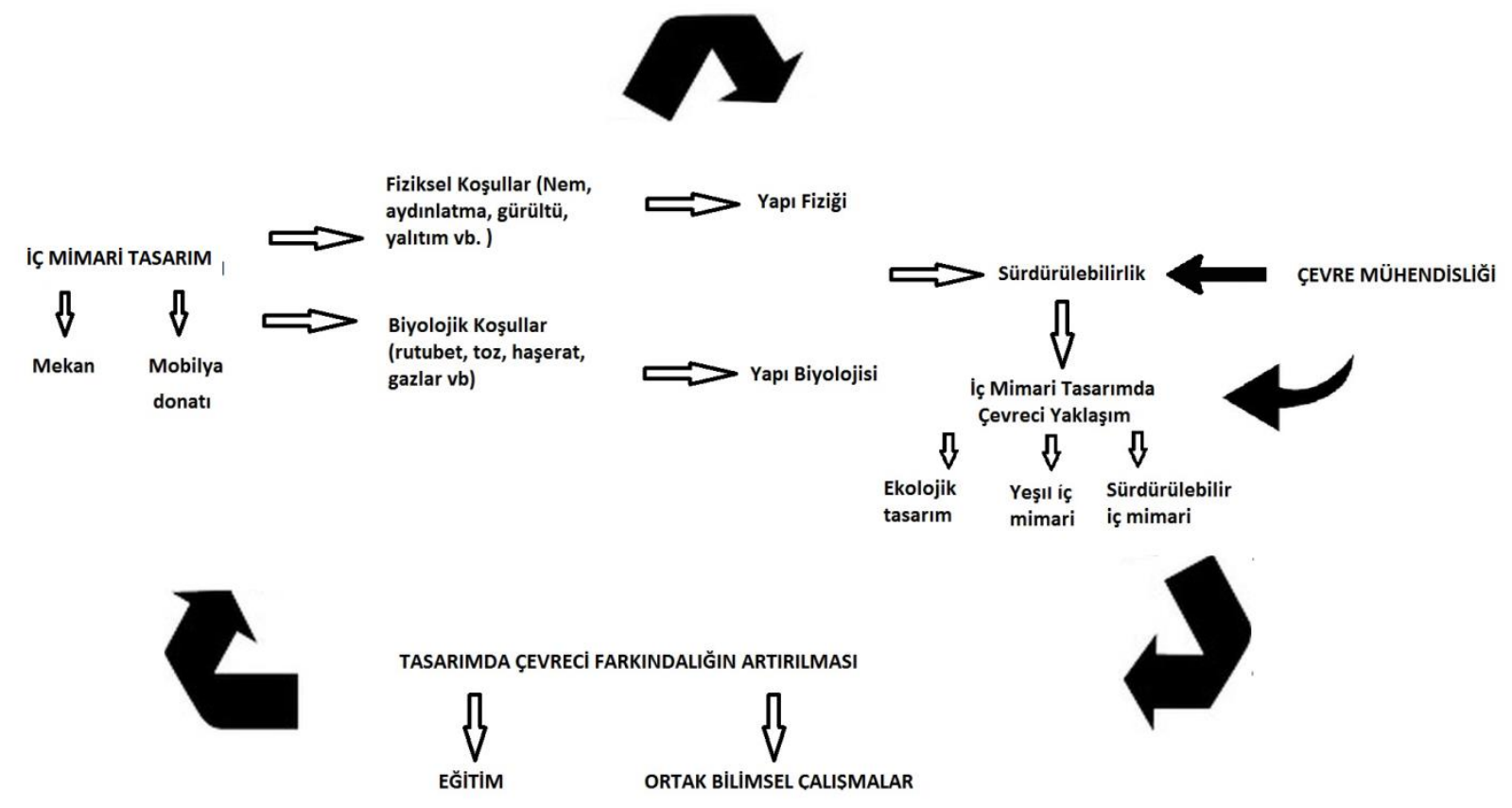

Şekil 17: Iç mimarlık ve çevre mühendisliği ilişkisi, girdi çıktılar ve ortak paydalar

Disiplinler arası çalışma kapsamında iç mimarlık uygulamalarının çevreci yaklaşımla ele alınmasında iç mimarlık ve çevre mühendisliği arasındaki ilişkinin kurulmasında şimdiye kadar ki bilgilere dayanılarak üç yöntem olduğunu söylemek mümkündür (Şekil 17):

○ Çok disiplinli yaklaşım ile iç mimarlık-çevre mühendisliği ilişkisinin kurulması: Direk olarak iki disiplinin ortak çalışabileceği konular arasında özellikle katı atıkların değerlendirme sürecinde iç mimari tasarımda atık kullanımı, geri dönüşüm çalışmaları, malzeme seçimi ve kullanımında malzemelerin ve uygulama yöntemlerinin çevreye etkilerinin belirlenmesi yani "Yapı Biyolojisi”, gürültü kirliliğinin önlenmesi, hasta bina sendromunun önlenmesi ve iç mekân hava kalitesinin sağlanması, yalıtım-çevre, tesisat-çevre ilişkilerinin kurulması vb. yapı fiziği çalışmalarında çevre mühendisliğinin danışmanlığına ihtiyaç duyulmaktadır. Ayrıca yenilenemeyen doğal kaynaklar olan ve yapıda kullanılan malzemelerin hammaddelerinin çıkarılıp, işlenip, taşınması, kullanımı ve bakımı, kullanımdan sonra tekrar işlemden geçirilerek yeniden kullanımı sürdürülebilir bir tasarım için gereklidir.

- Çapraz disiplinli yaklaşım ile iç mimarlık-çevre mühendisliği ilişkisinin kurulması: Yukarıda belirtilen ilişkilerin tasarım ve uygulama aşamasında kurulabilmesi için çevreci bir yaklaşım ile tasarım konusunda eğitim alanında çalışmalar yapılmalıdır. Son yıllarda çevreci yaklaşım ile iç mimari tasarım yaklaşımının tasarımcı adaylarına kazandırılabilmesi için iç mimarlık lisans ve lisansüstü programlarında ilgili dersler konulması önemli bir gelişmedir: İç mimarlık eğitiminde sürdürülebilir ve çevreci yaklaşımlar vb.

○ Disiplinler ötesi yaklaşım ile iç mimarlık-çevre mühendisliği ilişkisinin kurulması: Ekolojik-sürdürülebilir iç mimarlık ise çapraz disiplinli bir yaklaşım olmakla birlikte esasen sürdürülebilir bir dünya oluşturma çabaları kapsamında artık mekân tasarımı sadece bir tasarım disiplini olmaktan çıkmış, çevre mühendisliği konularının da özümsenerek tasarımlarda kullanıldığı sürdürülebilir, akıllı bina teknolojilerinin geliştirilmesi gelecekçi ve çevreci bir yaklaşım ile gündeme gelmiştir. Dolayısıyla iç mimarlıkta çevreci yaklaşımlar "Sürdürülebilirlik" kavramı (Ekolojik iç mimari, yeşil iç mimari, sürdürülebilir iç mimari) altında disiplinler ötesi bir yaklaşım oluşturmaktadır.

İki disiplin arasındaki ortak paydaların ve ortak çalışma alanlarının belirlenmesi gelecekçi iç mimarlık uygulamalarının yapılabilmesi açısından önem taşımakla beraber, tasarımda çevreci farkındalığın artırılmasına da yardımcı olacaktır. İç mimari tasarımda çevreci farkındalığın artırılması çevre mühendisliğinin temel ilkelerinin dikkate alınması yardımıyla eğitim ve ortak akademik çalışma alanlarının geliştirilmesi ile mümkün olacaktır.

Ayrıca, mekân tasarımıyla ilgili fütüristik yaklaşımlı çalışmalar da sürdürülebilir bir dünya oluşturmak amacıyla yapılan mekân tasarımlarında mühendislik dallarının temel ilkelerinden faydalanılması gerektiğini göstermektedir. Hatta yapılan tasarım çalışmaları ile gelecekte mekân tasarımı disiplinlerinin mesleki olarak değişime uğrayacağı, mimar, iç mimar gibi mesleklerin ortadan kalkacağı, tasarım ve mühendislik (makine, inşaat, çevre, elektrik gibi alanlarda) alanında özel olarak uzmanlaşmış bir tasarım mesleğinin ortaya çıkacağı vurgusu yapılmaktadır. Britanya 
Kraliyet Mimarları Birliği (Royal Institute of British Architects -RIBA)'in yapmış olduğu bir çalışmaya göre 20002050 yılları arasında küresel nüfusun artmasıyla birlikte, 2050 yılında nüfusun \% 70’i kentsel alanlarda yaşayacaktır. $\mathrm{Bu}$ durum da daha çok insan, daha çok yapılaşma ve daha büyük kentler ve yok olan çevre anlamına gelmektedir (İmamoğlu 2011). Dolayısıyla inşa edilecek mekânların çevreye duyarlı, enerji tasarrufu sağlayabilen ve sürdürülebilir olması için de tasarımın mühendislik ile ilişkilendirilmesi ve hatta "yapı mühendisi" adı altında tasarım ve mühendislik disiplinlerinin birlikte ele alındığı yeni bir mühendislik dalının ortaya çıkacağı öngörülmektedir (URL-21 2017; URL22 2017; Gilabert 2010).

Kısaca özetlemek gerekirse çevre duyarlı bir iç mimari tasarımda "sürdürülebilirlik" kavramı altında bir tasarım disiplini olan iç mimarlık yukarıda özetlenmiş bulunan konular ile ilgili olarak tasarımı yönlendirmek amacıyla çevre mühendisliği disiplininin temel bilgilerine ve danışmanlığına ihtiyaç duymaktadır. Tasarımda gelecekçi yaklaşımlar dikkate alındığında iki farklı disiplinin birlikte çalışması gereken ortamlar oluşacağı görülmektedir.

\section{Kaynaklar}

Adalberth K., (1996), Energy use during the life cycle of buildings: a method, Building and Environment, 32(4), 317-320.

Adıgüzel D., (2011), Türkiye'de iç mimarlık eğitiminde çevresel yaklaşım, Yüksek Lisans Tezi, Kadir Has Üniversitesi, İstanbul.

Aktan C., (2007), Yükseköğretimde değişim: Global trendler ve yeni paradigmalar, Yaşar Üniversitesi Yayını, İzmir.

Aktaş G.G., (2013), Design parameters and initiatives for ecological and gren design in interior architecture, WSEAS Transactions on Environment and Development, 2(9), 58-67.

Altuncu D., (2010), Sürdürülebilirlik açısından kompakt flüoresanlambaların incelenmesi, International Sustainable Buildings Symposium, Ankara, 810-812.

Ayalp N., (2013), Multidimensional approach to sustainable interior design practice, International Journal of Energy and Environment, 4(7), 143-151.

Chandramohan B., Fallows S., (2009), Interdisciplinary learning and teaching in higher education, Routledge, Londra, 184ss.

Crowther P., (2000), Building deconstruction in Australia, Overview of Deconstruction Selected Countries, (Charles Kibert and Abdol Chini Ed.) CIB Report, Florida.

Cooper D., (2014), Environmental Engineering, Waveland Press, New York.

Crowther P., (2001), Developing an inclusive model for design for ceconstruction, Deconstruction and Materials Reuse: Technology, Economic, and Policy, CIB Publication 266, New Zeeland, http://www.cce.ufl.edu/wp-content/uploads/2012/08/ Design for Deconstruction and Materials Reuse.pdf, [Erişim 30 Mart 2017].

Çelebi G., Gültekin A.B., Harputlugil G., Bedir, M., Tereci A., (2008), Yapı Çevre İlişkileri, Çizgi Basım Yayın Ltd. Şti, İstanbul.

Darçın P., (2014), Çevre duyarlı mimarlık, Mimarlık Dergisi (319), http://www.mimarlikdergisi.com/, [Erişim 30 Mart 2017$].$

Dennis L., (2010), Green interior design, Alworth Press, New York.

Demirarslan D., (2006), İc mekân tasarımına giriș, Kocaeli Üniversitesi yayınları, Kocaeli, 240ss.

Demirarslan D., Demirarslan K.O., (2008), Sürdürülebilirlik bağlamında geleceğe yönelik yaklaşımlar ve geri kazanım açısından mobilya tasarımının önemi, 1. Ulusal İç Mimarlık Sempozyumu, İstanbul, 114-127.

Demirarslan K.O., Demirarslan, D., (2008), Hava kirliliğinin mimari yapılar üzerindeki etkileri, Hava Kirliliği ve Kontrolü Ulusal Sempozyumu, Hatay, 194-207.

Demirarslan K.O., Demirarslan, D., (2016), Kentlerde yeni yerleşim alanlarının gelişsimi ve katı atık sorunu: İzmit Yahyakaptan mahallesi örneği, Doğal Afet ve Çevre Dergisi, 2(2), 108-120.

Dummet K., (2007), Designing for a sustainable future: Partnership to sustainability, Talking and Walking Sustainability Conference, Auckland.

Edwards B., (2001), Green architecture, Architectural Design, 4(71), 30.

Ehrlich P.R., Holdren J.P., (1971), Impact of population growth, Science, 171, 1212-1217.

Elias Özkan S.T., (2003), Binaların sökümü ve yıkımı, Ekoloji ve Mimarlık, Bülten, TMMOB Mimarlar Odası, Ankara, 38-41.

Erickson H.L. (1995), Stirring the head, herat and soul. Redefining curriculum and instruction. Corwin Press. Inc, California.

Eryıldız D., (2003), Sürdürülebilirlik ve mimarlık dosyasında ekolojik mimarlı, Arredamento Mimarlık Dergisi, 154, 71-75.

EURIMA, (2005), https://www.reeep.org/european-insulation-manufacturers-association-eurima, [Erişim 30 Mart 2017].

Fanger P.O., (2004), Enerjiden tasarruf sağlarken, iç hava kalitesi nasıl yüz kere daha iyi hale getirilebilir?, http://www.ttmd.org.tr/, [Erişiom 30 Mart 2017].

Faulkner D. C., (2007), Introduction to environmental design. Kendall Hunt, Dubuque, Iowa.

Fırat F.K., Akbaş F., (2015), İnşaat endüstrisinde geri dönüşüm çalışmalarının gelişstirilmesi ve ekonomi üzerine etkileri, Çevre ve Enerji Dergisi, 637- 644.

Fränzle S., Markert B., Wünschmann S., (2012), Introduction to Environmental Engineering, Wiley Press, Hong Kong.

Gilabert E.F., (2010), Ecologies of excess: an excerptfrom a 22nd century architecture history class, Architectural Design, 80(6), $72-$ 79.

Hasol D., (2012), Ansiklopedik mimarlık sözlüğü, Yem Yayınevi, İstanbul.

Hayles C., (2015), Environmentally sustainable interior design:A snapshot of current supply of and demand for green, sustainable or fair trade products for interior design, International Journal of Sustainable Built Environment, 4, 100-108.

İmamoğlu B., (2011), Riba'nın 2025 yılına yönelik araștırması, mimarlar için gelecek?, Mimarlık Dergisi, 360, http://www.mimarlikdergisi.com, [Erişim 30 Mart 2017].

Jacobs H., (1989), Interdisciplinary curriculum: Design and implementation. Association for Supervision and Curriculum Development, Alexandria. 
Jacobson M., (2002), Atmospheric pollutions history, science, and regulation, Cambridge University Pres, Cambridge. Kang M. (2004), The analysis of enviromentally sustainable interior design practice. Yayınlanmamış Doktora Tezi, Universty of Minesota, Minneapolis.

Kang M., Guerin D.A., (2009), Environmentally sustainable interior design: The characteristics of interior designers who practice, Environment and Behavior, 41, 170-184.

Kazamia K., Kafaridou M. (2010), How a designer can support sustainability in a creative way, International Design CongressDesign 2010, Dubrovnik, Crotia.

Kibert C.J., Chini, A.R., (2000), Deconstruction as an essential component of sustainable construction, Overview of Deconstruction in Selected Countries, CIB 2000 Report, Rotterdam.

Kurokawa K., (1977), Metabolism in architecture, Westview Press, Boulder.

Maczulak A., (2009), Environmental Engineering, Designing a Sustainable Future, Facts on File publishing.

Maroni M., Seifert B., Lindvall T., (1995), Indoor air quality. A comprehensive reference book. Vol.3, Elsevier, Tokyo.

Özmehmet E., (2007), Avrupa ve Türkiye'deki sürdürülebilir mimarlık anlayışına eleştirel bir bakış, Journal of Yasar University, 2(7), 809-826.

Özturan Ö., (2007), Teknolojik gelişmelerin iç mimarlı̆̆a etkisi, İç Mimarlık Dergisi. ttp://www.icmimarlikdergisi.com [Erişim 30 Mart 2017].

Piaget J., (1972), The epistemology of interdisciplinary relationships. Interdisciplinarity: Problems of teaching and research in universities. Paris: OECD.

Raven P.H., (2001), Atlas of population and environment, American Association Fort he Advancement of Science.

Salthammer T., (2004), Emissions of volatile organic compounds from products and materials in indoor environments, Indoor air quality, (Ed.) Peter Pluschke, Springer, Berlin, 37-71.

Samsunlu A., (2000), Türkiye'de çevre mühendisliği eğitimi üzerine düşünceler, Çevre Bilim Teknoloji Dergisi, 1 (1), 49-52.

Sev A., (2009), Sürdürülebilir mimarlı, Yem Yayınları, İstanbul.

Sylvan R. Bennet D., (1994), The greening of ethics, White Horse Press, Cambridge.

Taygun G., (2016), Kentsel dönüşümde asbest riski, Mimarlık dergisi (390): http://www.mimarlikdergisi.com, [Erişim 1 Haziran 2017]

TTGV, (2010), Temiz sürdürülebilir üretim raporu, Türkiye Teknoloji Geliștirme Vakfi, 265ss.

Uluatam S., (2011), İnşaat mühendisliğinde enerji verimliliği dersi, TMH - 468 - 2011/4, 59-66.

URL-1, (2017), http://w3.balikesir.edu.tr/ birol/modernizm.pdf [Erişim 30 Mart 2017].

URL-2, (2017), http://kongre.nigde.edu.tr/ [Erişim 30 Mart 2017].

URL-3, (2017), https://ifiworld.org/[Erişim 30 Mart 2017].

URL-4, (2017), http://www.csb.gov.tr/iller/mus/index.php?Sayfa=sayfa\&Tur=webmenu\&Id=11210, [Erişim 30 Mart 2017 ].

URL-5, (2017), web.deu.edu.tr/atiksu/ogrenci/ogr01.doc [Erişim 30 Mart 2017].

URL-6, (2017), http://www.cmo.org.tr/mesleki_denetim/yonetmelikler.php [Erişim 30 Mart 2017].

URL-7, (2017), https://ekonomi.isbank.com.tr/UserFiles/pdf/sr05_mobilyasektoru.pdf, [Erişim 30 Mart 2017].

URL-8, (2017), https:// nepis.epa.gov/Exc/24 Net.ex, [Erişim 30 Mart 2017].

URL-9, (2017), http://www.mobilyadergisi.com.tr/haber/turkiyede-yonga-ve-lif-levha-sektoru, [Erişim 30 Mart 2017 ].

URL-10, (2017), http://www.izto.org.tr/portals/0/argebulten/bulten_haziran_2013.pdf, [Erişim 30 Mart 2017].

URL-11, (2017), http://www.emlaktasondakika.com, [Erişim 30 Mart 2017].

URL-12, (2017), http://www.emlaktasondakika.com/, [Erişim 30 Mart 2017].

URL-13, (2017), http://3dkonut.com/kentsel-donusum-kapsaminda-20-milyon-konut-yikilacak-/haberi, [Erişim 30 Mart 2017]

URL-14, (2017), http://www.yfu.com/kitapciklar/gurultu.pdf, [Erişim 30 Mart 2017].

URL-15, (2017), https://sustainabledevelopment.un.org/, [Erişim 30 Mart 2017].

URL-16, (2017), http://www.cityfarmer.info/, [Erişim 30 Mart 2017].

URL-17, (2017), https://tr.pinterest.com/pin/551479916844085490/, [Erişim 30 Mart 2017].

URL-18, (2017), https://esiinteriors.wordpress.com/, [Erişim 30 Mart 2017].

URL-19, (2017), http://conceptsandcolorways.com/tag/sustainable-interior-design/, [Erişim 30 Mart 2017].

URL-20, (2017), https://blog.stateofgreen.com.au/ [Erişim 30 Mart 2017].

URL-21, (2017), http://www.asce.org/uploadedFiles/visionforthefuture.pdf, [Erişim 30 Mayıs 2017].

URL-22, (2017), https://dspace.mit.edu, [Erişim 30 Mayıs 2017].

WGSC, (2004), Working Group Sustainable Construction Methods and Techniques Final Report, http://ec.europa.eu/environment/ urban/, [Erişim 30 Mart 2017].

Wines J., (2008), Green architecture, Taschen Verlag GmbH, Köln, 240ss.

Yeang K., (2012), Ekotasarım: Ekolojik Tasarım Rehberi, Yem Yayınları, İstanbul, 472ss.

Yurtseven E., (2007), İki farklı coğrafi bölgedeki ilköğretim okullarında iç ortam havasının insan sağlı̆̆ına etkileri yönünden değerlendirilmesi, Doktora Tezi, İstanbul Üniversitesi, İstanbul. 